\title{
Selective Expression of Insulin-Like Growth Factor II in the Songbird Brain
}

\author{
Martin Holzenberger, ${ }^{2}$ Erich D. Jarvis, ${ }^{1}$ Christopher Chong, ${ }^{1}$ Matthew Grossman, ${ }^{1}$ Fernando Nottebohm, ${ }^{1}$ \\ and Constance Scharff ${ }^{1}$ \\ 1 The Rockefeller University, New York, New York 10021, and 2Institut d'Embryologie Cellulaire et Moléculaire, Centre \\ National de la Recherche Scientifique and Collège de France, F-94736 Nogent-sur-Marne Cédex, \\ Nogent-sur-Marne, France
}

Neuronal replacement occurs in the forebrain of juvenile and adult songbirds. To address the molecular processes that govern this replacement, we cloned the zebra finch insulin-like growth factor II (IGF-II) cDNA, a factor known to regulate neuronal development and survival in other systems, and examined its expression pattern by in situ hybridization and immunocytochemistry in juvenile and adult songbird brains. The highest levels of IGF-II mRNA expression occurred in three nuclei of the song system: in the high vocal center (HVC), in the medial magnocellular nucleus of the neostriatum (mMAN), which projects to HVC, and to a lesser extent in the robust nucleus of the archistriatum (RA), which receives projections from HVC. IGF-II mRNA expression was developmentally regulated in zebra finches. In canary HVC, monthly changes in IGF-II mRNA expression covaried with previously reported monthly differ- ences in neuron incorporation. Combining retrograde tracers with in situ hybridization and immunocytochemistry, we determined that the HVC neurons that project to area $X$ synthesize the IGF-II mRNA, whereas the adjacent RA-projecting neurons accumulate the IGF-II peptide. Our findings raise the possibility that within HVC IGF-II acts as a paracrine signal between nonreplaceable area X-projecting neurons and replaceable RAprojecting neurons, a mode of action that is compatible with the involvement of IGF-II with the replacement of neurons. Additional roles for IGF-II expression in songbird brain are likely, because expression also occurs in some brain areas outside the song system, among them the cerebellar Purkinje cells in which neurogenesis is not known to occur.

Key words: adult neurogenesis; Golgi; development; neurotrophins; growth factors
Discrete brain nuclei control the acquisition and production of learned song in songbirds. These nuclei include the high vocal center (HVC), the robust nucleus of the archistriatum (RA), and area X (Fig. 1) (Nottebohm et al., 1976, 1982). Whereas HVC and $\mathrm{RA}$ are required for the acquisition and production of learned song, area $\mathrm{X}$ is necessary for song acquisition, but not for production (Simpson and Vicario, 1990; Sohrabji et al., 1990; Scharff and Nottebohm, 1991).

There are two major classes of projection neurons in the HVC of male canaries and zebra finches: (1) those that synapse onto RA and continue to be produced and replaced during adulthood, and (2) those that project to area $\mathrm{X}$ and are produced only in ovo and not in adulthood (Alvarez-Buylla et al., 1988a; Nordeen and Nordeen, 1988a). Peaks in the recruitment of new RA-projecting neurons occur in adult canaries at times of the year when the birds develop new songs (Alvarez-Buylla et al., 1988a; AlvarezBuylla, 1992; Kirn et al., 1994; Nottebohm et al., 1994). Thus,

Received Feb. 25, 1997; revised June 5, 1997; accepted July 1, 1997.

This work was supported by Public Health Service Grants MH 18343 and 53542 and National Science Foundation Grant IBN-9319638. M.H. is a fellow of the European Communities Science Program. We thank Claudio Mello for assistance in constructing the cDNA library. José Garcia-Verdugo helped greatly with preparation and analysis of the semithin sections. Ed Vates generously provided material to confirm the anatomy of IGF-II expression in mMAN. John Kirn kindly supplied the original data for seasonal neuron incorporation and cell death. We thank Fiona Doetsch and David Vicario for valuable comments on this manuscript. We also gratefully acknowledge the insightful comments provided by two anonymous reviewers of this manuscript.

M.H. and C.S. contributed equally to this study.

Correspondence should be addressed to Dr. Constance Scharff, 1230 York Avenue, Box 137, New York, NY 10021.

Copyright (C) 1997 Society for Neuroscience $0270-6474 / 97 / 176974-14 \$ 05.00 / 0$ processes that are typically seen only in the developing mammalian brain, e.g., production, migration, and differentiation of new neurons, are ongoing events in the adult songbird brain. During development in other systems these processes seem to require the participation of trophic molecules, such as the insulin-like growth factors (IGFs), members of the fibroblast growth factor family (FGFs), and neurotrophins such as neurotrophin (NT) 3, NT4, brain-derived neurotrophic factor $(\mathrm{BDNF})$, and nerve growth factor (NGF). In addition, many of these trophic factors also play a role in the maintenance of the adult nervous system (for review, see Lo, 1995; Thoenen, 1995). Recently, it has been shown that BDNF and NT3 promote the survival of neurons in the developing song system (Johnson et al., 1997).

This paper focuses on one particular trophic factor, IGF-II. The IGFs are secreted growth-promoting peptides that are structurally related to insulin. They bind to specific cell surface receptors that activate second messenger pathways, ultimately regulating cell growth and/or differentiation. Their function has been studied in rodents and chicken; IGF-I and IGF-II are expressed throughout the embryonic rodent brain but are less expressed in adulthood (Bondy, 1991; Marks et al., 1991; Bondy et al., 1992; Bondy and Lee, 1993). IGF knock-out experiments (for review, see Ludwig et al., 1996) have shown that the naturally occurring levels of IGF expression are necessary for normal brain development. Other experiments have shown that IGFs regulate the survival of neurons during development (Quin-Wei et al., 1994; Johnston et al., 1996) and early postnatal life (D’Mello et al., 1993; Galli et al., 1995).

We have cloned the zebra finch IGF-II cDNA and used in situ hybridization (ISH), immunocytochemistry (ICC), and retrograde tracers to show very selective IGF-II expression in the 


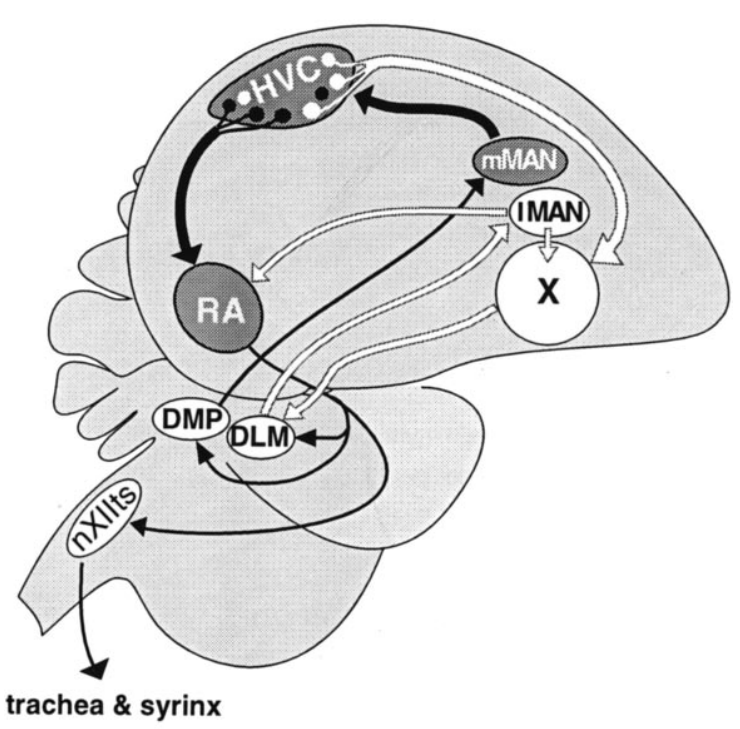

Figure 1. Diagram highlighting the song nuclei that express IGF-II mRNA (dark gray) and outlining their relationships (thick black arrows) as well as relationships among other song nuclei (thin black and white arrows). The two identified populations of projection neurons of $\mathrm{HVC}$, those that project to RA (black) and those that project to area X (white), are schematically indicated. The direct descending motor pathway includes $H V C$, the $R A$, and the tracheosyringeal portion of the hypoglossal nucleus (nXIIts). The anterior forebrain pathway is necessary for song acquisition and connects (white arrows) $H V C$, area $\mathrm{X}$ the medial portion of the dorsolateral thalamic nucleus $(D L M)$, and the lateral magnocellular nucleus of the anterior neostriatum $(I M A N)$, which continues to $R A$ and feeds back to area $\mathrm{X}$ (Okuhata and Saito, 1987; Bottjer et al., 1989; Nixdorf-Bergweiler et al., 1995; Vates and Nottebohm, 1995). Neurons in $R A$ give rise to two feedback loops. The first one connects RA with the posterior portion of the dorsomedial thalamic nucleus $(D M P)$, which in turn projects to the $m M A N$ that synapses with $H V C$ (Vates et al., 1997). The second feedback loop from $R A$ projects to the thalamic nucleus $D L M$, which in turn projects to IMAN (Wild, 1993; Vates et al., 1997).

songbird brain. Within the song system, expression was highest in HVC, in which the localization of mRNA and peptide was segregated into two different types of projection neurons, one renewable and the other stable. This paracrine mode of action within HVC suggests that IGF-II is a candidate molecule involved in neuronal turnover. To our knowledge this is the first report of anatomically restricted expression of a growth factor with neurotrophic potential in a subset of song system neurons.

\section{MATERIALS AND METHODS}

Animals. Canaries (Serinus canaria) and zebra finches (Taenopygia guttata) bred at the Rockefeller University Field Research Center (Millbrook, NY) were used for this study. Adult male canaries, ranging in age from 2.4 to 2.9 years $(n=14)$, were used to establish the IGF-II expression patterns throughout the CNS. Additional canaries (total $n=$ 47; 20-32 months old) were killed monthly between April 1995 and March 1996 for seasonal comparisons. Adult male zebra finches $(n=8)$ were used to establish their general IGF-II expression pattern. Twentyone male zebra finches, which become sexually mature at $\sim 90 \mathrm{~d}$, were killed at ages ranging from $36 \mathrm{~d}$ to 4.7 years to study the developmental mRNA expression of IGF-II in HVC. To establish which cell class in HVC was expressing IGF-II mRNA, we used eight adult canaries and six adult zebra finches. Adult, free-ranging, black-capped chickadee males (Parus atricapillus; $n=5$ ) were captured in October 1995 on the premises of the Rockefeller University Field Research Center and were used to confirm the pattern of IGF-II mRNA expression in free-ranging individuals. The IGF-II peptide distribution was studied immunocytochemically in 10 adult canaries and 6 zebra finches. Twenty-one adult canaries were used to establish which HVC neurons accumulated the IGF-II peptide.

$c D N A$ cloning. Total RNA was isolated from zebra finch embryos by the method of Chomczynski and Sacchi (1987). Poly(A $\left.{ }^{+}\right)$RNA was selected through oligo-dT cellulose columns (Pharmacia Biotech, Piscataway, NJ) and used to construct a size-selected cDNA library using the pSPORT kit of Life Technologies-Bethesda Research Labs (Gaithersburg, MD). Nylon replica filters (Hybond- ${ }^{+}$; Amersham, Arlington Heights, IL) containing $4 \times 10^{5}$ recombinant colonies were prepared and screened with a cDNA fragment containing $0.4 \mathrm{~kb}$ of the $5^{\prime}$ end of the chicken IGF-II coding region (Darling and Brickell, 1996; M. Holzenberger and C. Ayer-LeLièvre, unpublished observations) using the method of Hanahan and Meselson (1983). A 1.4 kb clone, pIGF-II-ZF, containing the complete open reading frame (ORF) of zebra finch IGF-II was isolated and manually sequenced (Sequenase version 2.0, United States Biochemical, Cleveland, $\mathrm{OH}$ ) using SP6 and T7 promoter primers (New England Biolabs, Beverly, MA) and IGF-II-specific primers synthesized at The Rockefeller University. The entire IGF-II ORF was sequenced on both strands. Regions containing unresolved compressions or ambiguities were resequenced with appropriate new primers. The final DNA sequence, assembled with GeneWorks (IntelliGenetics, Mountain View, CA), is shown in Figure 2 and was submitted to GenBank. The deduced amino acid primary sequence was compared with prepro-IGF-II from other vertebrates using GeneWorks (IntelliGenetics).

Radioactive ISH. ISHs were done as described previously (Jarvis et al., 1995; Mello and Clayton, 1995) with modifications. ${ }^{35}$ S-labeled sense and antisense riboprobes were generated from the zebra finch IGF-II plasmid clone pIGF-II-ZF, previously linearized with SalI or NotI, in the presence of SP6 (antisense) or T7 (sense) RNA polymerase, respectively; $1.5 \times 10^{6} \mathrm{cpm}$ of radiolabeled probe was applied to each slide in $80 \mu \mathrm{l}$ of hybridization solution. Sections were hybridized and washed at $65^{\circ} \mathrm{C}$; a final treatment with $5 \mu \mathrm{g} / \mathrm{ml} \mathrm{RNase} \mathrm{A}$ in $0.1 \times$ SSC for $10 \mathrm{~min}$ at room temperature was included to reduce background. Slides were exposed to $\mathrm{x}$-ray film for $5 \mathrm{~d}$ to determine signal intensity. Tissue sections were then coated with Kodak NTB2 photographic emulsion and stored in lighttight boxes with a desiccant for 8 weeks. After development, the sections were lightly counterstained with cresyl violet and observed with a microscope under bright- and dark-field illumination. For seasonal and developmental comparisons, sections from all animals were hybridized simultaneously to minimize procedural variability.

Quantification. Emulsion-dipped slides were analyzed using National Institutes of Health Image software. To measure expression levels specific for a given brain region, we measured the optical density of grains in a $100 \times 100 \mu \mathrm{m}$ area in this region and subtracted the equivalent value over an adjacent region of equal size. On average four sections per bird were measured, and the final value represents the means of these sections. Significant differences within seasonal and developmental comparisons were tested with one-way ANOVA; subcomparisons between individual groups were tested with Scheffé's $F$ tests and post hoc Student's $t$ tests.

Northern hybridization. Riboprobes for Northern hybridization were synthesized as described for ISH with the substitution of ${ }^{32} \mathrm{P}$ label for ${ }^{35} \mathrm{~S}$ label. Twenty micrograms of total RNA or $2 \mu \mathrm{g}$ of poly $\left(\mathrm{A}^{+}\right)$RNA per lane were electrophoresed through $1 \%$ agarose gels containing formaldehyde in $1 \times$ 3 -( $N$-morpholino)propanesulfonic acid (MOPS) buffer, as described in Sambrook et al. (1989). Gels were soaked for $1 \mathrm{hr}$ in $20 \times$ saline-sodium phosphate-EDTA (SSPE), and the RNA was blotted to Hybond-N ${ }^{+}$(Amersham). Blots were prehybridized for $15 \mathrm{~min}$ and then hybridized overnight at $65^{\circ} \mathrm{C}$, as described in Clayton et al. (1988). Filters were washed in four changes of $0.1 \times \mathrm{SSPE}$ and $0.1 \%$ SDS at $65^{\circ} \mathrm{C}$ for $15 \mathrm{~min}$ each and exposed to x-ray film at $-80^{\circ} \mathrm{C}$ with amplifying screens for 2 weeks.

Immunocytochemistry. Animals were perfused under deep anesthesia (Nembutal) with $60 \mathrm{ml}$ of PBS, followed by $60 \mathrm{ml}$ of $4 \%$ paraformaldehyde. Brains were removed and kept at $4^{\circ} \mathrm{C}$ in fixative for $16-20 \mathrm{hr}$. Sections were cut in the sagittal or frontal plane either on a vibratome (20 or $40 \mu \mathrm{m}$ ) or, after cryoprotection in $30 \%$ sucrose, on a freezing sliding microtome (14 or $20 \mu \mathrm{m}$ ). IGF-II-like immunoreactivity was detected using a polyclonal antibody against human IGF-II (Gropep, Australia). Cross-reactivity with chicken IGF-II in a radioimmunoassay was $100 \%$, but cross-reactivity with chicken IGF-I or ovine insulin was $<0.1 \%$. Sections were permeabilized with $0.1 \%$ Triton X-100 and blocked with $3 \%$ skim milk, and endogenous peroxidase activity was quenched with $0.3 \% \mathrm{H}_{2} \mathrm{O}_{2} / 10 \%$ methanol. Slides were then incubated overnight at $4^{\circ} \mathrm{C}$ with a 1:500 antibody dilution. After PBS washes, a biotinylated secondary anti-rabbit IgG (Sigma, St. Louis, MO) was used at 1:500 dilution. After avidin-biotin complex (ABC) amplification (Sigma), a nickelintensified diaminobenzidine (DAB) reaction resulted in a black precipitate indicating IGF-II-like immunoreactivity. Control reactions included the omission of primary antibody from the antibody dilution buffer, use 


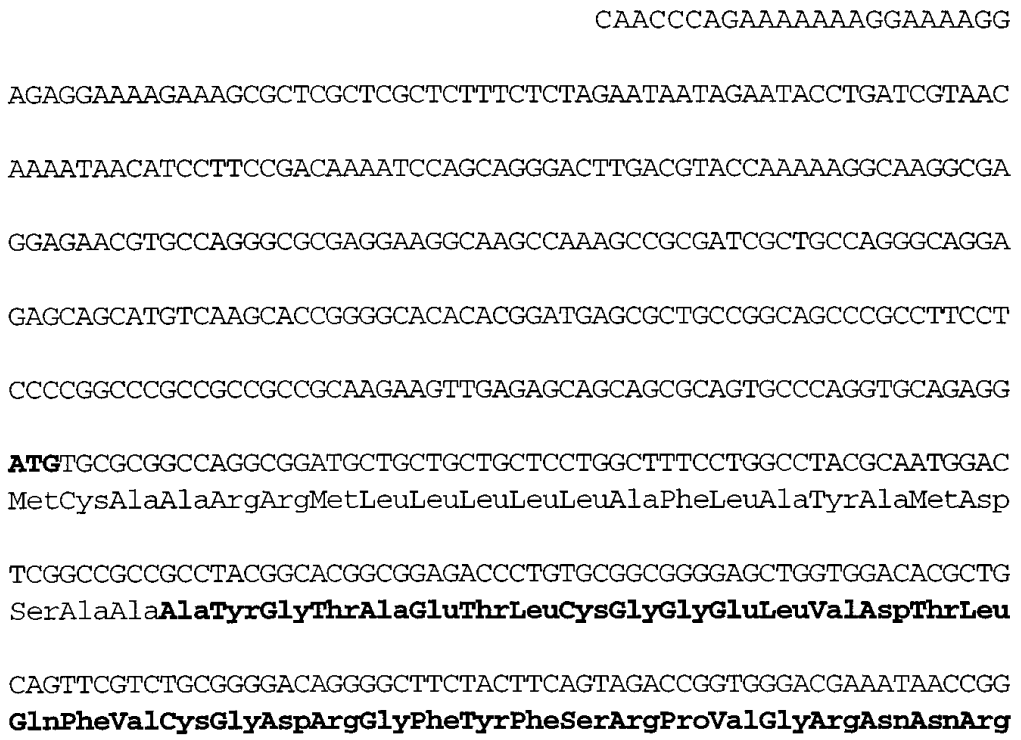
italics and starts at the $\mathrm{N}$ terminal of the mature IGF-II peptide.

of $\mathrm{ABC}$ plus $\mathrm{DAB}$ reaction only, use of $\mathrm{DAB}$ reaction only, and preabsorption of the primary antibody with $40 \mu \mathrm{M}\left[\mathrm{Gly}^{1}\right]$ IGF-II (Gropep), a recombinant analog of human insulin-like growth factor.

ICC with anti-mouse glial fibrillary acidic protein GFAP (Sigma) and with antibody $40 \mathrm{E}-\mathrm{C}$, which recognizes avian vimentin (Alvarez-Buylla et al., 1987), was done at dilutions of 1:400 and 1:100, respectively, with all other incubation steps as outlined above.

Double labeling with retrograde tracers, ISH, and ICC. To identify the classes of neurons in HVC that synthesize IGF-II mRNA and IGF-II peptide, we retrogradely labeled the area X-projecting or RA-projecting 

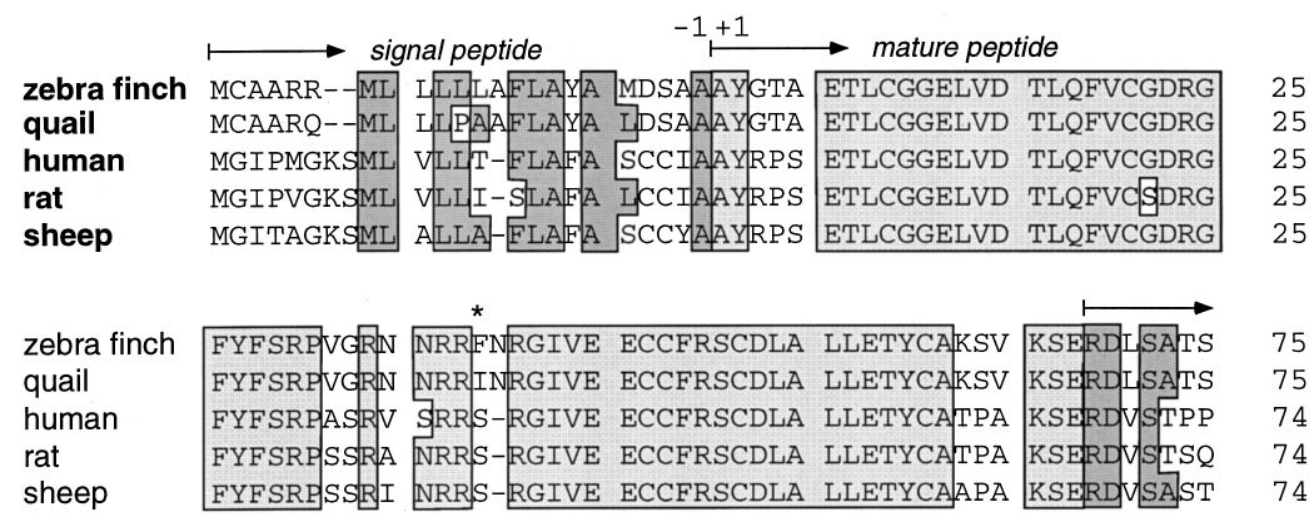

\section{5 \\ 75 \\ 74 \\ 74 \\ 74}

zebra finch

extension peptide

quail

human

rat

sheep
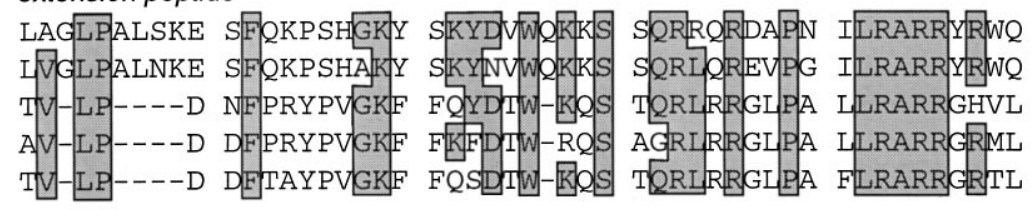

125

125

118

118

118

zebra finch

quail

human

rat

sheep

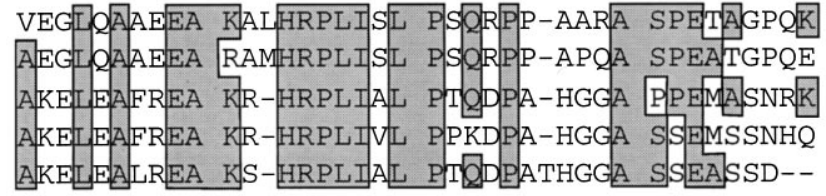

164

164

155

155

179
Figure 3. Amino acid sequence of zebra finch prepro-IGF-II and alignments with quail, human, rat, and sheep homologs. The numbering of residues (right) starts at the first position of the mature peptide. Insertions and deletions are indicated with dashed lines, and residues conserved between birds and mammals are boxed. Note that there is also considerable conservation among birds and also among mammals in the nonboxed areas. The mature IGF-II peptide includes the boxes shaded in light gray; signal and extension peptides include the boxes shaded in dark gray. The star indicates the only amino acid residue in which the mature IGF-II peptide differed between zebra finch and quail. neurons with rhodamine microspheres (Lumafluor, New York, NY) or with Fluorogold (Fluorochrome). This was accomplished by stereotaxically guided pressure injections of $50 \mathrm{nl}$ of tracer through glass micropipettes $(30 \mu \mathrm{m}$ in diameter) into RA or area X. Five days after tracer injections, brains were processed for ICC as outlined above and for nonradioactive ISH as described below.

Birds were decapitated, and their brains were quickly removed, placed in plastic block molds, surrounded with Tissue Tek (Miles, Elkhart, IN), immediately frozen in a dry ice and ethanol mix, and stored at $-80^{\circ} \mathrm{C} .10$ $\mu \mathrm{m}$ frozen sections were cut sagittally or frontally on a cryostat, mounted onto 3-aminopropyl triethoxysilane (Aldrich, Milwaukee, WI) (TESPA)coated slides, and stored at $-80^{\circ} \mathrm{C}$. Before hybridization, the sections were fixed in $3 \%$ paraformaldehyde in PBS for $5 \mathrm{~min}$ at room temperature, washed in three changes of PBS, and acetylated for $10 \mathrm{~min}$ in $1.4 \%$ triethanolamine with $3 \%$ acetic anhydride. The sections were washed in three changes of $2 \times$ SSPE and air-dried; dehydration by ethanol cannot be used because it dissolves the rhodamine microspheres.

Digoxygenin-labeled riboprobes were generated from linearized IGF-II plasmids in a $20 \mu \mathrm{l}$ reaction volume containing $1 \times$ transcription buffer (Promega, Madison, WI), $5 \mathrm{~mm} \mathrm{NaCl}, 10 \mathrm{~mm}$ dithiothreitol (DTT), $1 \mathrm{~mm}$ each ATP, CTP, and GTP, $0.5 \mathrm{~mm}$ UTP, $0.5 \mathrm{~mm}$ digoxygenin-11-UTP (Boehringer Mannheim, Indianapolis, IN), $1 \mu \mathrm{g}$ of linearized DNA template, $0.5 \mathrm{U}$ of RNasin (Promega), and $10 \mathrm{U}$ of T7 or SP6 RNA polymerase (Promega). After $1 \mathrm{hr}$ of incubation at $42^{\circ} \mathrm{C}$, another $10 \mathrm{U}$ of polymerase was added for a second hour. After synthesis, the DNA template was removed by treatment with $10 \mathrm{U}$ of DNase I for $10 \mathrm{~min}$ at $37^{\circ} \mathrm{C}$. RNA was precipitated with $0.3 \mathrm{M} \mathrm{NaOAc}, \mathrm{pH} 5.2$, and 2.5 volumes of $100 \%$ ethanol at $-70^{\circ} \mathrm{C}$ for $15 \mathrm{~min}$, microf uged for $20 \mathrm{~min}$, dried in a speed vacuum, and resuspended in $20 \mu$ l of diethylpolycarbonate (DEPC)-treated water. Probe concentration was determined empirically in side-by-side comparisons with an RNA standard (Boehringer Mannheim) on a $1 \%$ agarose gel.

Fifty nanograms of digoxygenin-labeled riboprobe were applied to each slide in a $36 \mu \mathrm{l}$ volume of hybridization solution containing $50 \%$ formamide, $2 \times \mathrm{SSPE}, 2 \mathrm{mg} / \mathrm{ml}$ tRNA, $1 \mathrm{mg} / \mathrm{ml}$ bovine serum albumin, $100 \mathrm{~mm}$ DTT, and $0.4 \mathrm{mg} / \mathrm{ml}$ poly $\left(\mathrm{A}^{+}\right)$. Sections were coverslipped and incubated in a slide rack for $3 \mathrm{hr}$ at $65^{\circ} \mathrm{C}$ in an oil bath. Oil was removed with chloroform, and coverslips were removed in $2 \times$ SSPE. Sections were washed for $1 \mathrm{hr}$ at room temperature in the same solution. High stringency washes were then performed in $2 \times$ SSPE containing $50 \%$ formamide at $65^{\circ} \mathrm{C}$ for $1 \mathrm{hr}$, in two subsequent changes of $0.1 \times \mathrm{SSPE}$ at $65^{\circ} \mathrm{C}$ for $30 \mathrm{~min}$ each, and then with $5 \mu \mathrm{g} / \mathrm{ml}$ RNase A in $0.1 \times$ SSC for $10 \mathrm{~min}$ at room temperature. The slides were finally rinsed in three changes of $0.1 \times$ SSC.

Slides were transferred into blocking solution containing $2 \times$ SSPE, $0.05 \%$ Triton $\mathrm{X}-100$, and $2 \%$ normal sheep serum (Sigma) for $1 \mathrm{hr}$ at room temperature. Slides were washed three times for 5 min each in TN buffer $(100 \mathrm{~mm}$ Tris, $\mathrm{pH} 7.5$, and $150 \mathrm{~mm} \mathrm{NaCl})$ and incubated overnight with anti-digoxygenin antibody (Boehringer Mannheim) at a 1:500 dilution in TN buffer with $1 \%$ normal sheep serum and $0.5 \%$ Triton X-100. Antibody was removed with four washes of $5 \mathrm{~min}$ each in TN buffer, and slides were equilibrated to $\mathrm{pH} 9.5$ by incubating for $10 \mathrm{~min}$ in $100 \mathrm{~mm}$ Tris, $\mathrm{pH} 9.5,100 \mathrm{~mm} \mathrm{NaCl}$, and $50 \mathrm{~mm} \mathrm{MgCl}_{2}$. Chromogenic detection was performed in the same buffer containing for every $1 \mathrm{ml}: 4.5 \mu \mathrm{l}$ of 75 $\mathrm{mg} / \mathrm{ml}$ nitrophenol blue (Fluka, Buchs, Switzerland) in $70 \%$ dimethylformamide, $3.5 \mu \mathrm{l}$ of $50 \mathrm{mg} / \mathrm{ml} \mathrm{X-phosphate} \mathrm{(Fluka)} \mathrm{in} 100 \%$ dimethylformamide, and $10 \mu \mathrm{l}$ of $24 \mathrm{mg} / \mathrm{ml}$ levamisole solution (Vector Laboratories, Burlingame, CA). A bluish-brown precipitate appeared within 30 min to $2 \mathrm{hr}$ over labeled cells. Doubled-labeled cells were photographed with double exposure, ISH or ICC under bright-field illumination and rhodamine or Fluorogold under UV illumination.

\section{RESULTS}

\section{cDNA cloning of songbird IGF-II}

A cDNA library was constructed from zebra finch embryos and screened with a chicken IGF-II cDNA. A $1.4 \mathrm{~kb}$ cDNA containing the ORF encoding the zebra finch prepro-IGF-II was isolated and sequenced (Fig. 2). There was $88 \%$ homology to quail cDNA (M. Holzenberger and C. Ayer-LeLièvre, unpublished observations) within the first $0.3 \mathrm{~kb}$ of the $5^{\prime}$-untranslated region (UTR); homology was $87 \%$ in the 561 bp coding region but only $65 \%$ in the 3 '-UTR, where several deletions and insertions were found (data not shown). Compared with quail, the deduced 68 amino acid sequence of the mature peptide from zebra finch showed only one substitution (residue 39, Fig. 3). This residue was located within a stretch of 10 amino acids (residues 31-40) that shows increased sequence variability when mammalian and avian IGF-II 
A

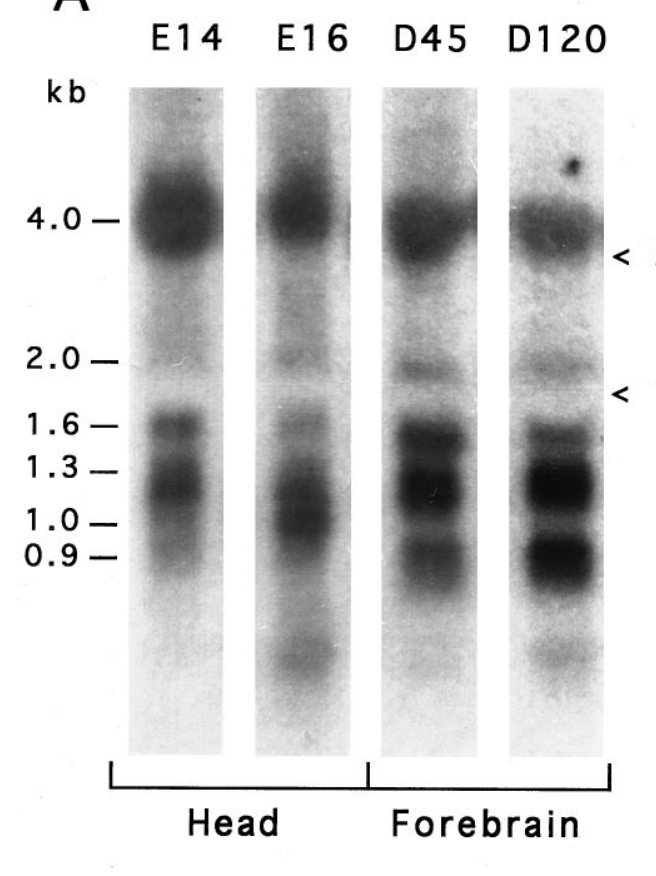

B

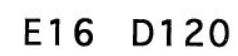

Figure 4. Northern analysis of zebra finch total and poly $\left(\mathrm{A}^{+}\right)$-selected RNA. $A$, Samples of total RNA from the head region of embryonic day 14 (E14) and E16 embryos and from the forebrain of 45-d-old (D45) and D120 birds were hybridized with the IGF-II antisense riboprobe, revealing multiple transcripts ranging in size between 0.9 and $4.0 \mathrm{~kb}$. $B$, The sense probe showed no hybridization to RNA samples from embryonic head (E16) or adult forebrain $(D 120)$. $C$, After poly $\left(\mathrm{A}^{+}\right)$ selection of embryonic (pooled E6-E14) RNA and hybridization with the antisense probe under identical conditions, a $4.0 \mathrm{~kb}$ mRNA was recognized. Ribosomal RNA locations $28 S$ and $18 S$ were determined from the ethidium bromide-stained gel. are compared (Fig. 3). Homologies in signal and extension peptides were lower ( $83 \%$ for both).

Northern hybridization of total RNA from zebra finch embryonic and adult brain (120-d-old) showed the presence of multiple IGF-II transcripts ranging from 0.9 to $4.0 \mathrm{~kb}$ in size (Fig. $4 A$ ). No signal was detected in control hybridizations with the sense probe (Fig. $4 B$ ), indicating that the expression pattern seen in Figure $4 \mathrm{~A}$ is IGF-II specific. After poly $\left(\mathrm{A}^{+}\right)$selection from embryonic total RNA, only a single band remained, the $4.0 \mathrm{~kb}$, when hybridized with the antisense probe (Fig. 4C).

\section{IGF-II mRNA expression pattern in song nuclei}

There was a high level of IGF-II mRNA expression in HVC of 100 canaries, zebra finches, and black-capped chickadees inspected (Fig. 5). Comparably high levels were seen only in choroid plexus and leptomeninges (Figs. $6 H, 7 A$ ). Two other song control nuclei, mMAN and RA, also showed IGF-II expression, but there was no such expression in song nuclei area $\mathrm{X}$ and IMAN. In both zebra finches and canaries, the relative expression levels, as judged by density quantification of ISH label, differed significantly among HVC, mMAN, and RA (ANOVA, $n=7$; $F=8.3 ; p=0.003$ for canaries $)(n=8 ; F=15.6 ; p=0.0001$ for zebra finches). In canaries, HVC-specific label density was on average sixfold higher than RA-specific label density but only 1.7-fold higher than mMAN-specific label density. In each canary quantified $(n=7)$, the relative relationship of label intensity was $\mathrm{HVC}>\mathrm{mMAN}>\mathrm{RA}$. In individual zebra finches, the relative expression levels among $\mathrm{HVC}, \mathrm{RA}$, and mMAN were more variable than in canaries. On average, HVC density in zebra finches was eightfold higher than mMAN density and threefold higher than RA density, but two of the eight adult zebra finches quantified had higher expression levels in RA than in HVC.

High magnification showed that only subsets of cells in HVC, RA, and mMAN expressed IGF-II mRNA (Fig. 6). In all three nuclei, IGF-II-positive cells were evenly distributed throughout the nucleus, and the anatomical borders of the nucleus coincided sharply with the limits of high IGF-II expression. The labeled cells had large cell bodies, a pale cytoplasm, and one or two well defined, darkly staining nucleoli, suggesting a neuronal phenotype. Within HVC, the IGF-II mRNA-positive cells often formed part of cell clusters, which typically contained one and sometimes more IGF-II mRNA-positive cells surrounded by several others that did not express the gene (Fig. 6E). The ventricular zone in which neuronal progenitor cells reside (Goldman and Nottebohm, 1983) did not contain IGF-II mRNA-positive cells (Fig. 6A,C). Isolated cells expressing high levels of IGF-II mRNA were found in the region traversed by axons going from $\mathrm{HVC}$ to RA. Some of those cells (data not shown) appeared to be glia, based on their size and Nissl-staining properties.

A crescent-shaped layer of cells expressing high levels of IGF-II was sometimes observed on the caudal border of the caudomedial neostriatum (NCM), just subjacent to the lateral ventricle (Fig. $5 C$ ). These cells are either adjacent to or part of the region of $\mathrm{NCM}$ that has been shown to be involved in song discrimination (Chew et al., 1995).

\section{IGF-II mRNA expression pattern in other brain areas}

We found widespread low-level IGF-II mRNA expression in parts of the neostriatum, hyperstriatum accessorium, and hyperstriatum ventrale as well as in the hippocampus and parahippocampus in all animals of the three species studied (Fig. 5). IGF-II-positive cells in the hippocampal complex were arranged in a layer parallel to the lateral ventricle (Fig. 7A); the majority of these cells was of medium to large size and apparently neurons, judged by their Nissl-staining profile, and more cells were labeled in proximity to the ventricle than toward the brain surface. This latter distribution is reminiscent of that of the new neurons added to the hippocampus of adult black-capped chickadees (Barnea and Nottebohm, 1994). Consistent labeling was also seen in the archifrontal tract, in which small, densely packed, apparently glial cells expressed IGF-II (Fig. 5A). The rest of the telencephalon [e.g., lobus parolfactorius (LPO) including area $\mathrm{X}$ and ectostriatum] had no or very low IGF-II mRNA expression.

IGF-II mRNAs were present in several pontomesencephalic 

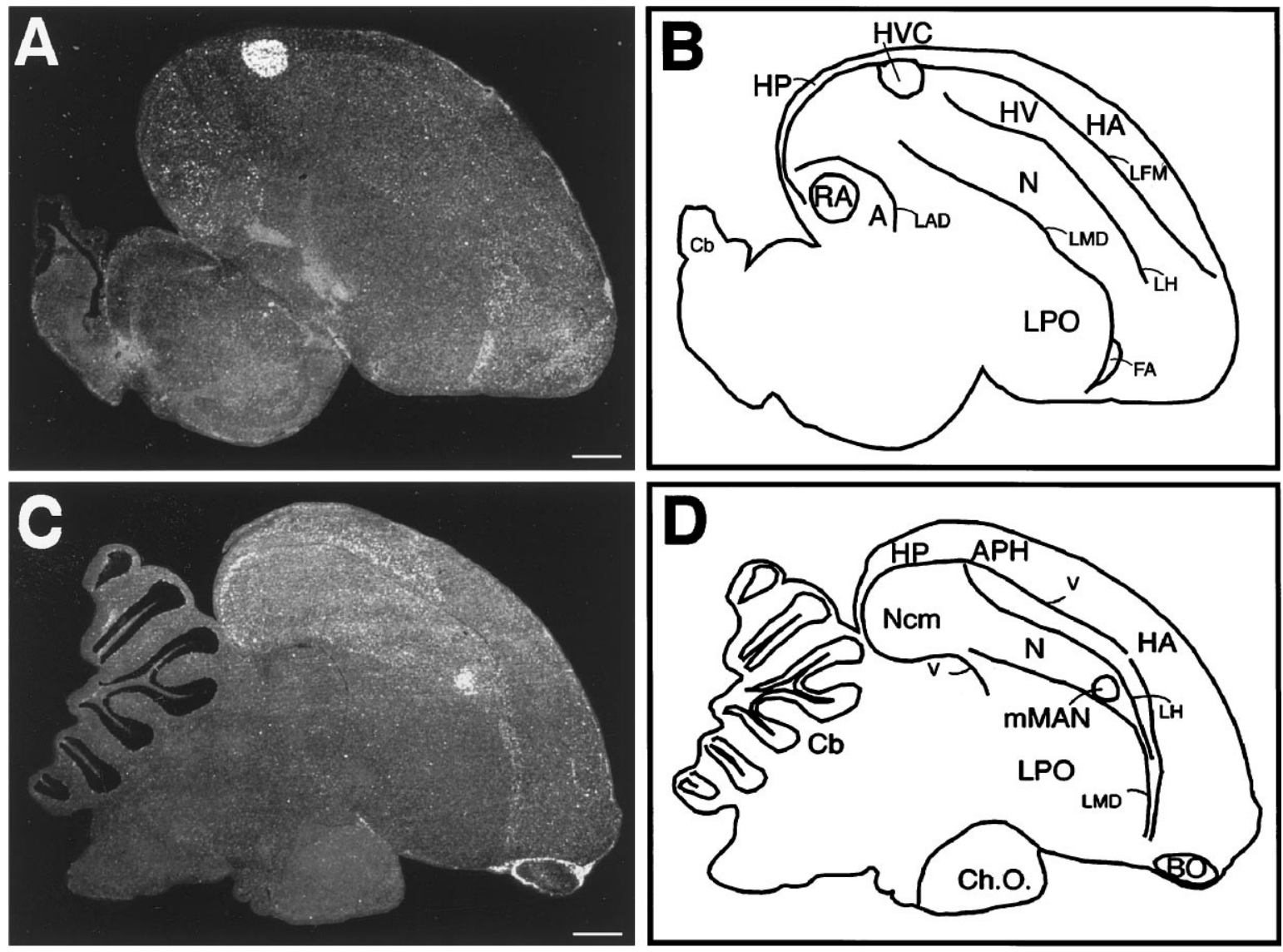

Figure 5. IGF-II mRNA expression in song nuclei of a 2.5 -year-old canary. $A$, In a dark-field photomicrograph of a parasagittal section $\sim 2 \mathrm{~mm}$ from the midline, a strong IGF-II mRNA ISH signal is seen as white silver grains overlying HVC and to a lesser extent over RA. $C$, Approximately $500 \mu \mathrm{m}$ from the midline, mMAN shows a strong IGF-II mRNA signal. A crescent-shaped area with selective expression is visible in the most caudal reaches of $\mathrm{Ncm}$ as well as a layer of cells in the parahippocampus. Leptomeninges have been stripped off the brain during dissection except around the olfactory bulb, in which they show the characteristically strong IGF-II expression. $B, D$, Anatomical diagrams of sections shown to the left. $A$, Archistriatum; $A P H$, area parahippocampalis; $B O$, olfactory bulb; $C b$, cerebellum; $C h . O$., chiasma opticum; $F A$, frontoarchistriatal tract; $H A$, hyperstriatum accessorium; $H P$, hippocampus; $H V$, hyperstriatum ventrale; $L A D$, lamina archistriatalis dorsalis; $L F M$, lamina frontalis suprema; $L H$, lamina hyperstriatica; $L M D$, lamina medularis dorsalis; $L P O$, lobus parolfactorius; $N$, neostriatum; $N c m$, caudomedial neostriatum. Scale bars, $1 \mathrm{~mm}$.

nuclei, including the area ventralis of Tsai (AVT) (Fig. 7E), nucleus tegmenti pedunculopontinus pars compacta (TPc), and nucleus pontis lateralis (PL). Cerebellar Purkinje cells and several deep cerebellar nuclei expressed IGF-II mRNA in an otherwise IGF-II-negative cerebellum (Fig. 7C). There also was some IGF-II expression in the central layer of the olfactory bulb (data not shown). Leptomeninges and the choroid plexus, which are known to be sources of IGF-II in the embryonic and adult vertebrate brain, also expressed IGF-II mRNA in songbirds (Figs. 5C, 7A, $G$ ).

Negative control hybridizations included in each hybridization series using the IGF-II sense riboprobe produced uniform low background signals (Figs. $6 B, D, F, 7 B, D, F, H$ ). ISH using a cRNA from the chicken IGF-II coding region or radiolabeled chicken IGF-II-specific oligonucleotides (M. Holzenberger and C. Ayer-LeLièvre, unpublished observations) gave identical results to those observed using the zebra finch probe, confirming the specificity of the expression pattern.

\section{Developmentally regulated IGF-II mRNA expression in zebra finch HVC}

We studied the IGF-II mRNA expression levels in HVC during three phases of zebra finch development related to known times of neural (Nordeen and Nordeen, 1988b; Burek et al., 1990) and behavioral (Immelmann, 1969; Price, 1979; Eales, 1985) plasticity: (1) between posthatching days 36 and 54 during the stage that corresponds to early song development, (2) between posthatching days 65 and 75 when juvenile zebra finches are in late plastic song, and (3) in adults, ranging from $93 \mathrm{~d}$ to 4.7 years old, a period when song is crystallized and stable. The level of IGF-II expression in HVC differed significantly among younger juveniles (mean age of $42 \mathrm{~d}$ ), older juveniles (mean age of $68 \mathrm{~d}$ ), and adults as shown in Figure 8. Older juveniles had significantly higher IGF-II expression than either younger juveniles or adults $(p<0.01$ and $p<0.001$, respectively). The younger juvenile birds had more IGF-II label than adults, but not significantly more. Other song nuclei, e.g., RA, area $\mathrm{X}$, and IMAN, did not exhibit elevated IGF-II mRNA levels during the developmental time period studied.

\section{Seasonal regulation of IGF-II mRNA expression}

Song plasticity, blood testosterone levels, neuronal recruitment, and cell death in HVC change significantly during the annual reproductive cycle of adult male canaries (Nottebohm et al., 1987; Kirn et al., 1994), so we were curious to establish whether IGF-II expression might also be seasonally regulated. We compared IGF-II expression levels in HVC of an average of four canaries (range, 2-6) per month throughout an entire year, starting in April 

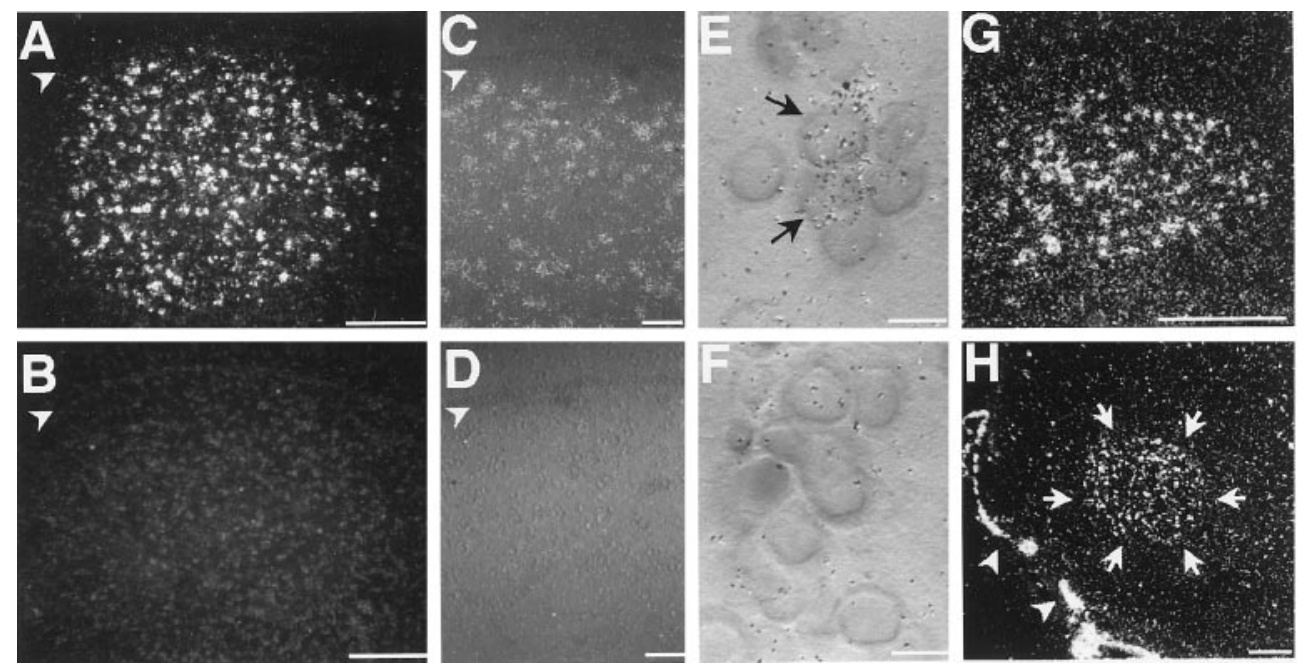

Figure 6. Cellular expression of IGF-II mRNA in canary $(A, C, E, G)$ and zebra finch $(H)$ song nuclei and negative controls $(B, D, F)$ hybridized with the sense probe. $A, \mathrm{HVC}$ shows a uniform distribution of IGF-II-labeled cells and a homogeneous signal intensity throughout the area. Arrowheads $(A-D)$ indicate the position of the lateral ventricle. $C$, Higher magnification reveals that not all cells in $\mathrm{HVC}$ are labeled and that the ventricular zone is negative. $E$, Within the cell clusters typical for HVC, IGF-II mRNA is often expressed in a subset of HVC cells (black arrows) surrounded by IGF-II negative cells. Nomarski optics highlight cell nuclei as darker, round profiles surrounded by a lighter-appearing cytoplasmic region, the boundaries of which cannot be seen. The grain distribution of the upper IGF-II-positive cell indicates labeled mRNA both in the cytoplasm overlying the nucleus and in the cytoplasm extending beyond the nucleus to the top right. $B, D, F$, In control sections hybridized with the sense strand, adjacent to those sections shown in $A$, $C$, and $E$, respectively, label is not different from background. $G$, IGF-II is strongly expressed in adult canary mMAN. $H$, IGF-II-positive cells are uniformly distributed in adult zebra finch RA, although this intensity of label was rare. White arrows indicate the anatomical outline of the RA; white arrowheads point to the IGF-II-positive meninges. All photomicrographs were obtained from parasagittal sections (dorsal is at the top, and rostral is to the right) under dark-field $(A, B, G, H)$ or Nomarski illumination $(C-F)$. Scale bars: $A, B, 500 \mu \mathrm{m} ; C, D, 50 \mu \mathrm{m} ; E, F, 10 \mu \mathrm{m} ; G, H, 250 \mu \mathrm{m}$.
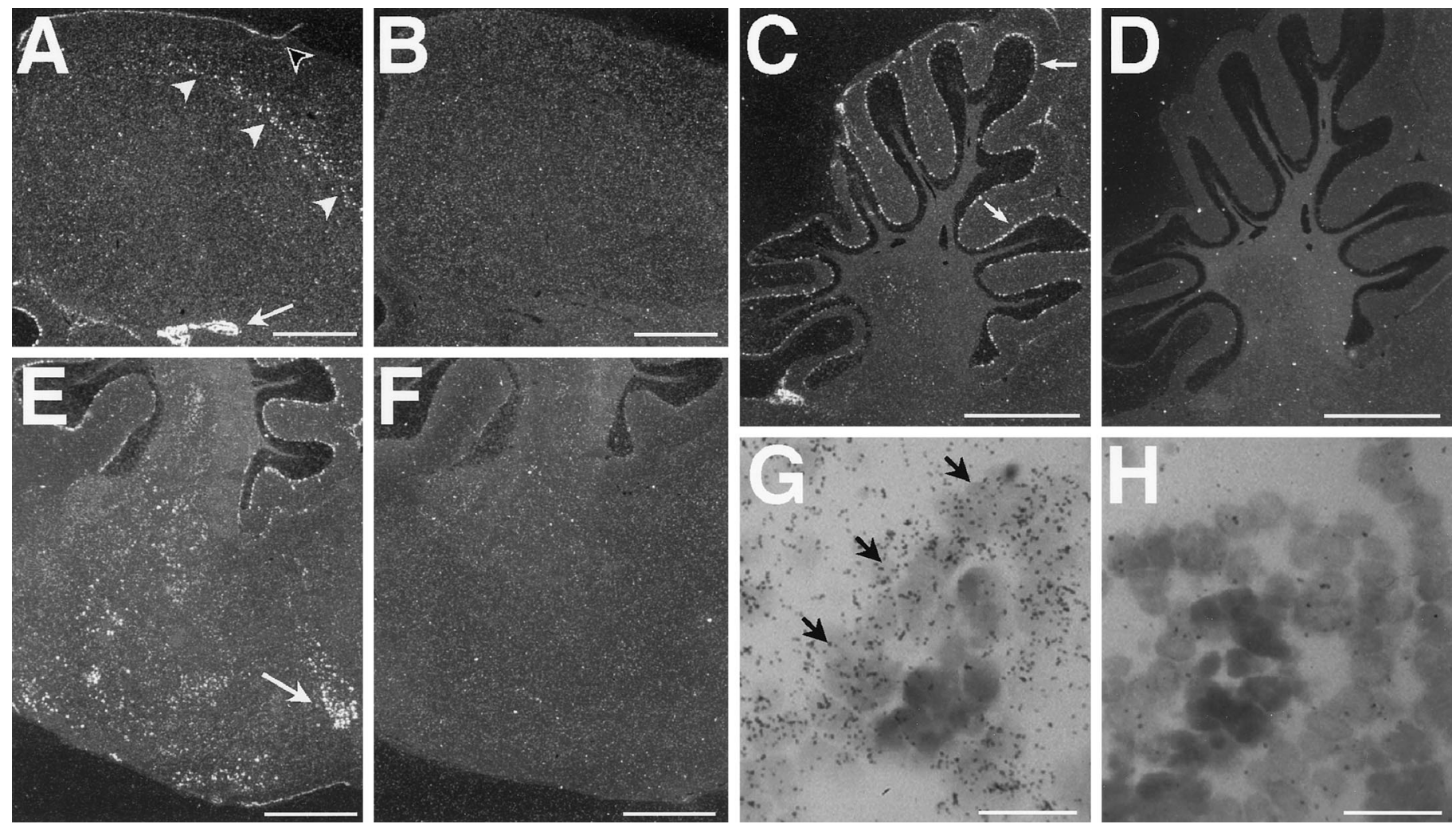

Figure 7. Conspicuous IGF-II mRNA expression was found in the hippocampus $(A)$, cerebellar Purkinje cells $(C)$, brainstem $(E)$, and choroid plexus $(A$, $G) . B, D, F, H$, Negative controls hybridized with the sense probe show signals not different from background. $A$, A low-magnification dark-field photomicrograph shows a streak of IGF-II-positive cells (white arrowheads) in the hippocampus of an adult canary. The IGF-II-positive meninges are indicated with a black arrowhead. Note also that the choroid plexus (white arrow) is strongly labeled. $C$, Cerebellar Purkinje cells, shown here in an adult zebra finch, were strikingly labeled (arrows). Often deep cerebellar nuclei were also positive. E, Several pontomesencephalic nuclei showed IGF-II mRNA expression, among them AVT (arrow) shown here in a dark-field photomicrograph of an adult canary section. $G$, A high-power light-field photomicrograph shows that IGF-II mRNA is primarily expressed in the epithelium (arrows) of the choroid plexus, shown here in an adult zebra finch. All sections are cut in the parasagittal plane $\sim 500 \mu \mathrm{m}$ from the midline; dorsal is at the top, and caudal is to the left. Scale bars: $A-F, 1 \mathrm{~mm} ; G, H, 10 \mu \mathrm{m}$. 


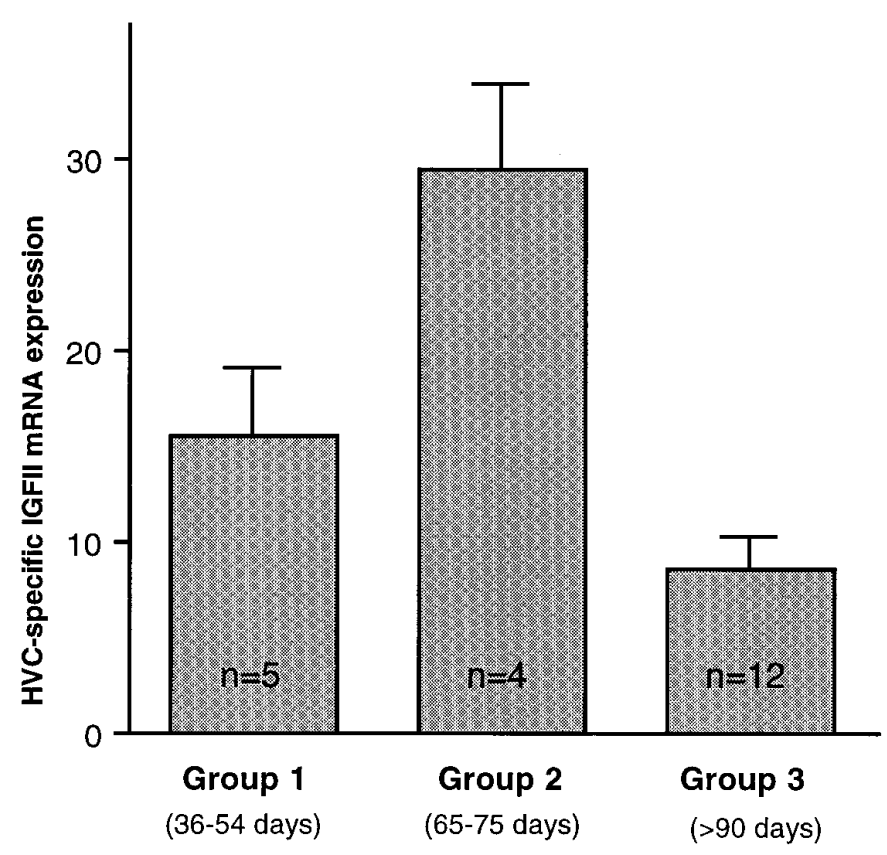

Figure 8. Developmental regulation of zebra finch HVC-specific IGF-II mRNA expression, quantified by image analysis of ISH signal. IGF-II levels in $\mathrm{HVC}$ were highest in group 2 (mean age of $68 \mathrm{~d}$ ). Both younger juveniles (group 1, mean age of $42 \mathrm{~d}$ ) and adults (group 3, between $93 \mathrm{~d}$ and 4.7 years old) had significantly lower levels (group 1 vs group $2, p=$ 0.0001 ; group 2 vs group $3, p<0.05$; group 1 vs group $3, p>0.05$ ). HVC-specific expression was obtained by subtracting the grain density values measured in an area ventral to $\mathrm{HVC}$ from those measured inside HVC. The group differences are caused by changing mRNA expression within HVC because expression patterns in the area below HVC did not vary among groups. The differences between groups are expressed in optical density units, and error bars indicate SEM. Significances were calculated using ANOVA and Scheffé's $F$ tests and post hoc Student's $t$ test comparisons (ANOVA, $n=21 ; F=14 ; p=0.0002$ ).

and ending in March, and found that the average monthly levels across the 12 month period changed but that these changes were not significantly different, owing partly to high intramonth variability (one-way ANOVA, $n=45 ; F=1.2 ; p>0.05$; Fig. 9B). However, when we compared our observations on IGF-II mRNA levels in $\mathrm{HVC}$ with the published data on neuronal recruitment in the same nucleus (Fig. 9A,B) in birds of comparable age, we saw that the month-to-month changes in both curves were in the same direction for 10 of the 11 transitions. In fact, the monthly changes in neuronal recruitment covaried significantly with the monthly changes in IGF-II mRNA expression (Fig. $9 C ; n=11 ; r=0.595$; $p<0.05)$. No other previously studied seasonally varying parameters (cell death, testosterone or estrogen levels, and syllable addition) covaried with IGF-II expression levels ( $p>0.05$ in all cases).

\section{Immunocytochemical localization of IGF-II in the adult brain}

HVC showed conspicuous and specific IGF-II-like immunoreactivity in all brains analyzed $(n=23)$ (Fig. 10A). The boundaries defined by the IGF-II immunoreactivity coincided with the Nisslstained boundaries of HVC in adjacent sections. Preincubation of the antibody with recombinant IGF-II peptide abolished the specific IGF-II staining in HVC (Fig. 10B) and in all other parts of the brain ( $n=2$; data not shown). Often, some cells in a neuronal cluster within HVC would show the antibody label whereas others were negative. The label occurred as numerous oval or curved profiles located in proximity to the nucleus of cells
(Fig. 10C). This pattern suggested that the immunoreactivity was localized to the Golgi or late endosomal compartment. Analysis of $1 \mu \mathrm{m}$ plastic sections supported this interpretation (data not shown). Also mMAN was always immunopositive (Fig. 10D,E), but in this case the label was not Golgi-like but diffusely present throughout mMAN. Interestingly, some canaries (4 of 10) showed Golgi-like staining in IMAN, although of less intensity than in HVC in the same brain. We did not find IGF-II-like immunoreactivity in RA or area $\mathrm{X}$.

In addition to the ICC label seen in HVC and mMAN, the radial cells typical of adult songbird forebrains were always strongly IGF-II-immunoreactive (Fig. 10H,I). Most of these radial cells had their cell bodies in the ventricular zone of the lateral wall of the lateral ventricle and had a long, single, undivided process that reached into the brain parenchyma. The radial cells of adult canaries are vimentin-positive and serve as guides for the initial dispersal of the newly generated neurons (Alvarez-Buylla et al., 1987, 1988b). The ventricular zone throughout the lateral ventricle showed punctate IGF-II immunoreactivity (Fig. 10K). Also immunopositive was a population of stellate cells with a morphology reminiscent of microglia (Fig. 10F, G). Both radial cells and stellate cells often contacted microvasculature. The stellate cells were negative to antibodies against avian GFAP and vimentin, markers for astrocytes (data not shown). Expression of IGF-II mRNA in stellate cells was found throughout the brain, although with varying densities; e.g., they were much more abundant in the LPO than in neostriatum (Fig. 10G). IGF-IIimmunoreactive stellate cells were never observed in HVC, and only very few were seen in RA, although in the surrounding brain tissue in both cases this cell type was commonly detected. Cerebellar Purkinje cell bodies had faintly positive cytoplasmic immunoreactivity, but strong varicose immunoreactivity was seen on what appeared to be the Purkinje cell dendrites extending into the molecular layer of the cerebellum (data not shown).

\section{Retrograde identification of IGF-II-positive neurons in HVC}

To identify which HVC neurons expressed IGF-II mRNA and which accumulated IGF-II peptide, we combined injection of two retrograde tracers, Fluorogold and rhodamine microspheres, with either IGF-II nonradioactive ISH or ICC (total $n=21$ ). The smaller RA-projecting neurons often cluster around area X-projecting neurons (Kirn and Nottebohm, 1990). When we injected rhodamine microspheres into area $\mathrm{X}$ and performed nonradioactive ISH on sections containing $\mathrm{HVC}$, we found that all of the cells within HVC that were retrogradely filled with rhodamine microspheres also showed IGF-II mRNA label. Thus, area X-projecting neurons accounted for $>85 \%$ of IGF-II mRNA-positive HVC cells (mean, 87\%; range, 75-92\%; six animals; three sections per HVC) (Fig. $11 A, B)$. The small proportion of IGF-II mRNA-positive cells that was not retrogradely labeled from area $\mathrm{X}$ could be either another cell class such as interneurons, glia, RA-projecting cells, or area X-projecting cells that had not been backfilled by the rhodamine beads. The possibility that these are RA-projecting cells was tested by retrogradely labeling RA-projecting cells with rhodamine microspheres $(n=4)$. In this case, none of the rhodamine-labeled RA-projecting cells was IGF-II mRNA-positive. Instead, IGF-II mRNA was often detected in the cells immediately adjacent to the RA-projecting, rhodamine-labeled cells (Fig. 11C,D). Thus, within HVC, IGF-II mRNA is likely to be produced mainly and possibly exclusively by the area X-projecting neurons. Interest- 

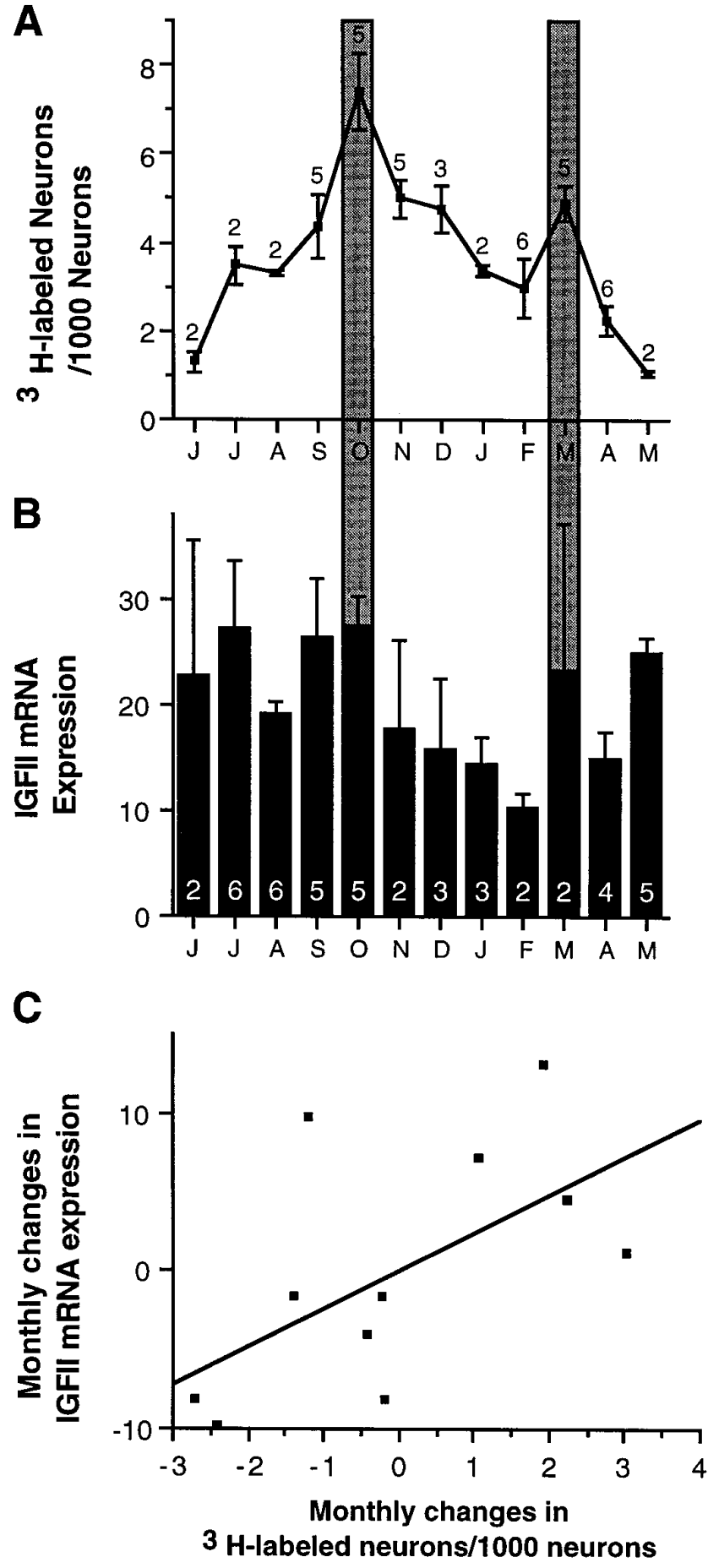

Figure 9. Comparison of seasonal variation of $(A)$ neuron addition and $(B)$ IGF-II mRNA expression in HVC of male canaries between 1 and 2 years of age, sampled each month throughout a 12 month period. $A$, Neuron addition to the HVC was not the same during all months (ANOVA, $F=7.3 ; p=0.0001$ ); Reproduced with permission from Kirn et al. (1994). $B$, HVC-specific IGF-II mRNA was present at varying levels throughout the year, but differences were not statistically significant (ANOVA, $n=45 ; F=1.2 ; p=0.3448$ ). However, a comparison of $A$ and $B$ shows that significant peaks in neuron addition coincide with (relative to surrounding months) high IGF-II mRNA levels (October and March, darkly shaded bars). Moreover, month-to-month changes are in the same direction for both neuron addition and IGF-II levels, with the exception of April to May. $C$, Monthly changes in neuron addition and IGF-II levels covary significantly $(n=11 ; r=0.595 ; p<0.05)$. Monthly changes in neuron addition were calculated from the original data generated by Kirn ingly, the strip of superficial area X-projecting neostriatal cells abutting HVC medially, termed paraHVC (pHVC) by Johnson and Bottjer (1995), did not show IGF-II double-labeled area $\mathrm{X}$-projecting cells (data not shown); in fact, $\mathrm{pHVC}$ was devoid of IGF-II mRNA-positive cells.

To assess the distribution of IGF-II peptide in HVC, we injected in the same bird rhodamine microspheres into area $\mathrm{X}$ and Fluorogold into RA $(n=7)$. In striking contrast to the distribution of the mRNA, IGF-II immunoreactivity did not coincide with the retrogradely rhodamine-labeled area X-projecting neurons (Fig. $11 E, G$ ). Instead, the Fluorogoldlabeled RA-projecting cells were positive for the IGF-II peptide (Fig. $11 F, G)$. In fact, it was rare to encounter a Fluorogold-labeled cell that did not also exhibit IGF-II peptide label. Thus, within HVC, it seems that only the RA-projecting neurons accumulate the IGF-II peptide to immunocytochemically detectable levels. Consistent with this interpretation is also the observation that $\mathrm{pHVC}$, which is devoid of RAprojecting cells, did not show IGF-II peptide labeling.

\section{DISCUSSION}

\section{Cloning of the zebra finch IGF-II cDNA}

In agreement with previous findings in mammals (Lund et al., 1986; Beck et al., 1988) and chicken (Taylor et al., 1991), Northern hybridization of IGF-II total RNA from songbird forebrain revealed multiple transcripts; only one of these mRNA species, the $4.0 \mathrm{~kb}$, was enriched by poly $\left(\mathrm{A}^{+}\right)$selection, as was observed in rats (Graham et al., 1986). This suggests that the smaller mRNA species detected in total RNA are not polyadenylated. The different transcript sizes could be attributable to RNA processing, alternative polyadenylation signals leading to different lengths of $3^{\prime}$-UTRs, or initiation of transcription at different promoters resulting in different length $5^{\prime}$-UTRs (Nielsen, 1992). The variability in the $5^{\prime}$-UTRs has been proposed to be correlated with different subcellular localizations. Our results suggest that transcriptional events leading to multiple transcripts may be as complex in birds as in mammals.

The $1.4 \mathrm{~kb}$ zebra finch clone we isolated contains the entire coding region of the IGF-II prepropeptide and parts of the $5^{\prime}$ - and $3^{\prime}$-UTRs. The more distal portions of the UTRs are not present in our clone, resulting in a cDNA that is smaller in size than the $4.0 \mathrm{~kb}$ seen in the poly $\left(\mathrm{A}^{+}\right)$Northern hybridizations. Our zebra finch clone was similar in size to a quail IGF-II cDNA also obtained from an oligo-dT-primed embryonic library (M. Holzenberger and C. Ayer-LeLièvre, unpublished observations). The presence of strong secondary structures in the UTRs may lead to inefficient reverse transcription, generally resulting in smaller cDNAs. Sequencing of the more distal $3^{\prime}$-UTR of quail IGF-II (M. Holzenberger and C. Ayer-LeLièvre, unpublished observations) revealed several poly $\left(\mathrm{A}^{+}\right)$-rich regions, upstream of the poly $\left(\mathrm{A}^{+}\right)$-tail, where oligo-dT-initiated cDNA synthesis could have started, providing another explanation for the shorter $3^{\prime}$ UTR in our cDNA.

et al. (1994) and were used to plot $A$. Monthly changes in IGF-II expression levels were calculated from the data shown in $B$. Each point on the scatterplot $(C)$ represents one monthly transition, e.g., June-to-July, Julyto-August, etc. The letters on the $x$-axis for $A$ and $B$ are the first letter for each month of the year, starting on the left with June. 

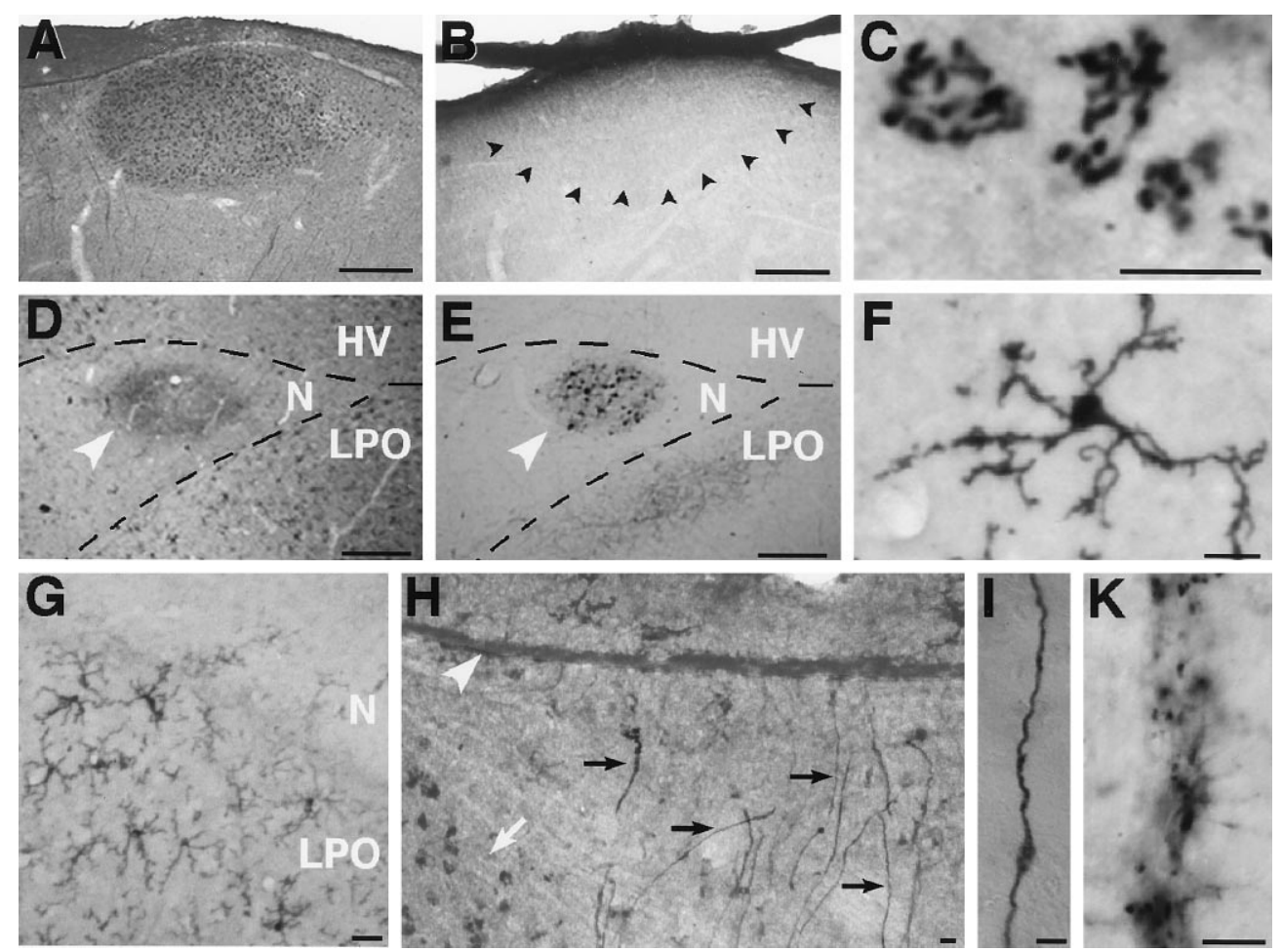

Figure 10. IGF-II immunoreactivity in parasagittal sections of adult canary forebrain. $A$, Immunoreactive material accumulates within $\mathrm{HVC}$ but is absent in neurons from the surrounding tissue. $B$, Preincubation of the antibody with human recombinant IGF-II abolishes specific IGF-II immunoreactivity in HVC. The anatomical outline of $\mathrm{HVC}$ is indicated with arrowheads. The hippocampus overlying $\mathrm{HVC}$ has detached from the section and partially overlaps with the dorsal edge of HVC. $C$, At high magnification the IGF-II peptide staining is perinuclear and curvilinear, a pattern suggesting Golgi-associated localization. $D$, IGF-II immunoreactivity is present in mMAN, indicated by an arrowhead. E, Anatomical identification of mMAN (arrowhead) by means of retrogradely biotinylated dextranamine-labeled neurons, as described in Vates et al. (1997). F, IGF-II antibody also stains a stellate cell type, probably microglia. $G$, IGF-II-positive stellate cells are much more abundant in LPO than in neostriatum. $H$, The radial cells typical of the adult songbird brain showed strong IGF-II immunoreactivity in their processes. A white arrow indicates the anterior edge of HVC in which IGF-II-positive cells can also be seen. The lateral ventricle overlying HVC is marked by an arrowhead. I, Close-up of a radial fiber with its characteristic thickening. K, Punctate staining in the ventricular zone of the lateral ventricle indicates the presence of IGF-II immunoreactive material. $H V$, Hyperstriatum ventrale; $L P O$, lobus parolfactorius; $N$, neostriatum. Scale bars: $A, B, D, E, 500 \mu \mathrm{m} ; C, F-I, K, 10 \mu \mathrm{m}$.

\section{IGF-II expression pattern in the songbird brain}

Two findings stand out. First, the IGF-II gene is selectively and strongly expressed in neurons of HVC of songbirds. Previously, robust IGF-II mRNA expression in adult vertebrate brain had been seen only in cells of non-neuroepithelial lineage, e.g., choroid plexus, leptomeninges, and vascular endothelial cells (Bondy et al., 1992; Couce et al., 1992; Sullivan and Feldman, 1994), all of which expressed IGF-II in our study also. Second, the HVC neurons that produce the IGF-II mRNA are members of the stable, nonreplaceable population that projects to area $\mathrm{X}$, whereas the replaceable neurons that project to RA (Alvarez-Buylla et al., 1990; Kirn et al., 1991) accumulate the IGF-II peptide in the Golgi/late endosomal compartment. This suggests a paracrine mode of IGF-II action in a particularly interesting brain region that shows remarkable adult plasticity (neuronal replacement) and controls a quantifiable, learned motor behavior (song).

Why does the IGF-II peptide of the RA-projecting cells accumulate in the Golgi/late endosomal compartment? In mammals and birds, IGF-II binds to the IGF type 1 receptor, a tyrosine kinase, activating a second messenger cascade (for review, see LeRoith et al., 1995) that is thought to mediate the mitogenic and metabolic actions of IGF-II (for review, see Nielsen, 1992; Efstratiadis, 1994). In mammals, but not in birds, IGF-II also binds to the IGF-II/mannose 6-phosphate receptor (IGF type 2 receptor/ $\mathrm{M} 6 \mathrm{PR})$. This IGF type 2 receptor functions in receptor-mediated endocytosis and cycles between the cell membrane and the Golgi network in a pathway that seems to be involved in rapid internalization and degradation of excess IGF-II (for review, see Nielsen, 1992). Consistent with this, immunoreactive detection of the IGF-II peptide as well as accumulation of radiolabeled IGF-II in the Golgi apparatus has been seen in mammalian tissues (Mossner et al., 1986; Kotani et al., 1993). The IGF type 2 receptormediated rapid turnover pathway in mammals is essential for perinatal survival of mice, as has been convincingly argued by combinatorial knock-outs of the IGF type 1 and 2 receptors and of IGF-II itself (for review, see Ludwig et al., 1996). Interestingly, the avian M6PR does not have an IGF-II binding site, and other than the type 1 receptor (Holzenberger et al., 1996), no alternative avian IGF type 2 receptor has yet been identified (Zhou et al., 1995). However, the immunoreactive staining we observe in HVC suggests that a type 2-like receptor-mediated endocytic pathway exists in birds, leading to accumulation of IGF-II in the Golgi/late endosomal compartment.

\section{Functional implications of IGF-II in HVC}

Because IGF-II mRNA is produced in the area X-projecting cells of $\mathrm{HVC}$ and the peptide is found in the RA-projecting cells of HVC, IGF-II secreted by the area X-projecting neurons may act locally. A more remote, but possible, source of IGF-II peptide in HVC could be the mMAN neurons that project into HVC. This 

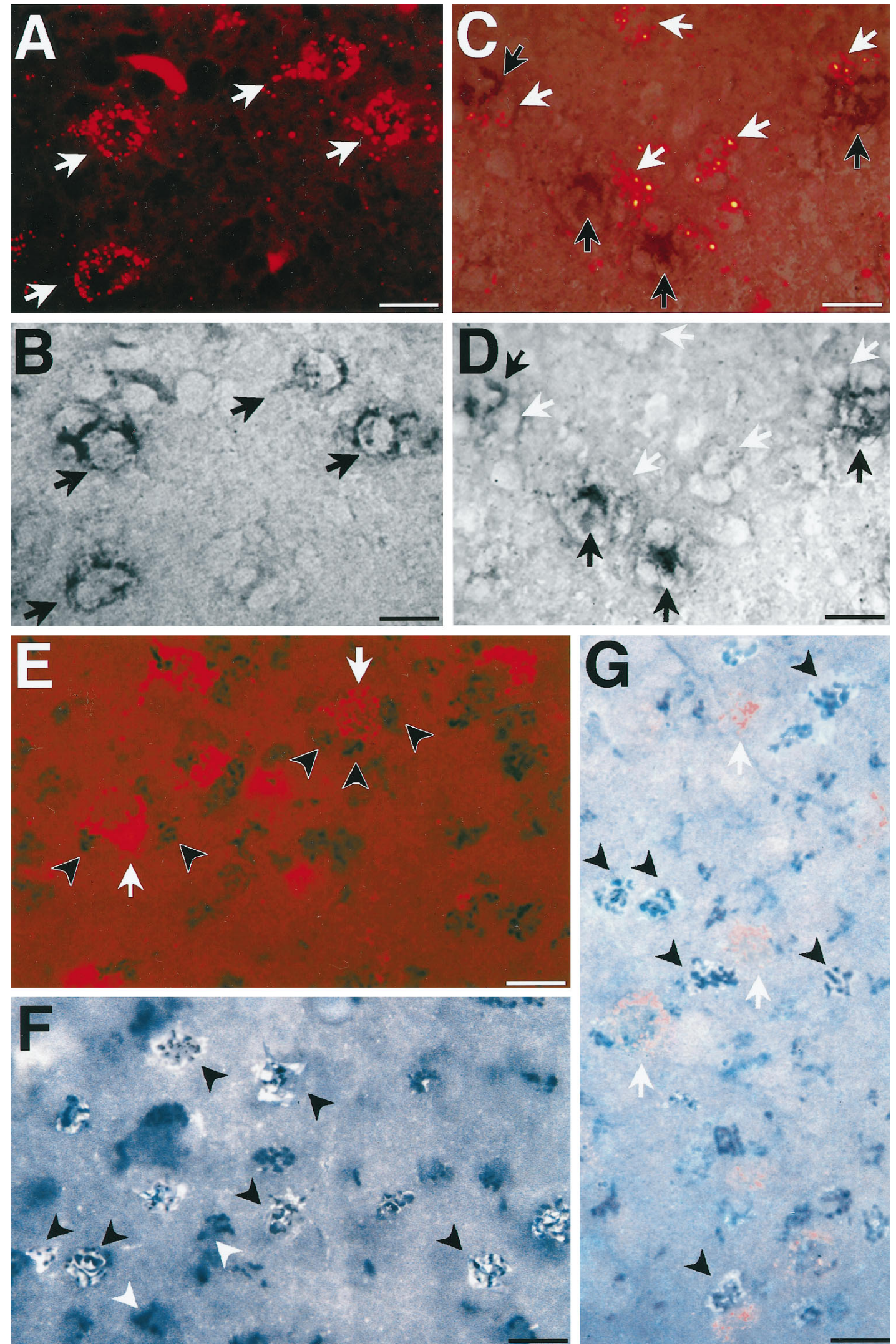
type of orthograde transport has been observed for IGF-I in the olivary-cerebellar system (Nieto-Bona et al., 1993) and for BDNF and NT3 in songbirds (Johnson et al., 1997). Whatever the source, the presence of IGF-II in HVC could protect a subset of RA-projecting cells from cell death while others die and are replaced. A precedent for the ability of neurotrophins to protect neurons in the song system from apoptosis has recently been described (Johnson et al., 1997). The potential of IGFs to prevent neuronal apoptosis has been demonstrated in cerebellar granule cells (D'Mello et al., 1993; Galli et al., 1995) and in the spinal cord (Quin-Wei et al., 1994). Recently, IGF-II has been demonstrated to prevent apoptosis in a variety of non-neuronal cells in vitro (Polychronakos et al., 1995; Stewart and Rotwein, 1996; Ueda and Ganem, 1996).

Our observation that monthly changes in neuron incorporation covary with monthly changes in IGF-II expression levels in HVC raises the possibility that relatively higher levels of IGF-II facilitate the incorporation or survival of new HVC neurons. However, IGF-II could also act directly on ventricular zone stem cells that give rise to new neurons (Goldman and Nottebohm, 1983), as attested by the punctate immunoreactivity present in the ventricular zone. A direct action of IGF-II on neurogenesis would be in line with the control of cell proliferation in other systems (Edbladh et al., 1994; Zackenfels et al., 1995). It is possible, too, that the amount of singing influences IGF-II expression, as has been reported recently for two immediate early genes (Jarvis and Nottebohm, 1997; Kimpo and Doupe, 1997), and we are currently examining this.

Additional evidence of the potential importance of IGF-II in the life of new neurons in HVC stems from our observation that IGF-II mRNA expression in HVC was higher during development than in adulthood. The connections of HVC to its two efferent targets, RA and area X, are well established by day 35 (Konishi and Akutagawa, 1985; Mooney and Rao, 1994), but significant numbers of new neurons are added to zebra finch HVC until $\sim 50-60$ d of age, coinciding with the major sensorymotor integration phase of song learning (Nordeen and Nordeen, 1988a,b). The intriguing peak in IGF-II mRNA expression in older (65-75 d) juvenile zebra finches coincides with the closing of the sensory-motor integration phase and may have something to do with the consolidation of connections that underlie the learned song pattern. This could occur via neurite extension and synapse formation, effects that IGF-II has been shown to facilitate in other systems (Liu and Lauder, 1992; Konishi et al., 1994). In summary, although our data on seasonal and developmental fluctuations of IGF-II mRNA levels in HVC are not conclusive, they suggest a role for IGF-II in the generation, maturation, and survival of new neurons in the song system.

\section{Functional implications of IGF-II in other areas of the brain}

The proposed role of IGF-II in HVC might not apply to the rest of the brain. It is worth noting that both the hippocampus and NCM, which showed IGF-II mRNA expression, exhibit adult neurogenesis (Barnea and Nottebohm, 1994; F. Nottebohm, unpublished observations) and are implicated in mediating memory formation (Krebs et al., 1989; Chew et al., 1996). We also found IGF-II mRNA expressed in the olfactory bulb, as has been observed in chicken and mammals (Ayer-Le Lièvre et al., 1991; Lee et al., 1993). Again, adult neuronal recruitment is well documented in this area (Altman, 1969; Kaplan et al., 1985; Lois and Alvarez-Buylla, 1994) and seems to be regulated by behavior (Corotto et al., 1994). Conversely, no new neurons are added to the cerebellum of adult songbirds, where we detected IGF-II expression, or to the cerebellum of adult rodents (Altman and Bayer, 1993), where IGF-I is expressed and necessary for the acquisition of a simple learning paradigm (Castro-Alamancos and Torres-Aleman, 1994). An explanation for this coincidence of IGF expression with behavioral plasticity and/or recruitment of new neurons is that IGF-II may be involved in processes that are prominent in areas of active remodeling, whether because of neuronal turnover requiring neurite extension and synaptic remodeling or because of learning-induced changes in neuronal architecture.

Our understanding of regional IGF-II distribution is certainly not complete. For example, we noticed variable presence of IGF-II mRNA, but no peptide, in RA neurons. Translational discrimination of the various IGF-II mRNA transcripts or lack of immunoreactivity in areas with only moderate or low IGF-II peptide levels are possible explanations for this. Furthermore, peptide levels in mMAN were low and diffuse, whereas the mMAN neurons showed solid mRNA expression. Intriguingly, in some instances IMAN, which was not seen to express IGF-II mRNA, had Golgilike peptide staining associated with its neurons, raising the possibility that IGF-II secreted by mMAN neurons finds its way to the adjacent IMAN. No anatomical connection between these nuclei so far has been described. Finally, we found strong immunopositive IGF-II staining in some areas that have little if any IGF-II mRNA expression (e.g., the stellate cells in LPO). Similarly, the radial cells, the cell bodies of which abut the lateral ventricle, accumulate peptide along the length of their process but show no mRNA production in their cell body. These cells may take up IGF-II from

\footnotetext{
$\leftarrow$

Figure 11. Combined labeling with retrograde neuronal markers, nonradioactive ISH, and ICC in canary brain. $A$, HVC was photographed under fluorescent light for the identification of area X-projecting neurons, labeled with retrogradely transported rhodamine microspheres (red label, white arrows). $B$, The same field shown in $A$ under bright-field illumination shows the presence of IGF-II mRNA detected by nonradioactive ISH (black label, black arrows) in the area X-projecting cells identified in $A$. C, Retrogradely rhodamine (bright red)-labeled RA-projecting neurons (white arrows) do not overlap with, but are adjacent to, nonradioactive IGF-II ISH-labeled neurons (black arrows). $D$, Bright-field photomicrograph of the same field shown in $C$ focusing on the same ISH-labeled cells dimly visible in $C$. White arrows point to the absence of ISH label in the places in which rhodamine-positive RA-projecting cells are visible in C. E, Combination of retrograde labeling with ICC showed that IGF-II immunoreactivity (black label, black arrowheads) is not present in, but is adjacent to, the area X-projecting neurons (red label, white arrows). F, Double labeling using the IGF-II antibody (black, photographed under bright-field illumination) and retrograde Fluorogold filling of the HVC-to-RA-projecting neurons (white, photographed under UV illumination) indicates that IGF-II immunoreactivity accumulates in these cells (black arrowheads). The majority of IGF-II-positive cells is Fluorogold-labeled, but a few immunopositive cells are not backfilled (white arrowheads) G, Triple-labeled HVC section shows IGF-II-specific immunoreactivity overlying Fluorogold-labeled RA-projecting cells (black arrowheads), whereas rhodamine microsphere-labeled area X-projecting cells (white arrows) are immunonegative. Cells in the focal plane of the photo most clearly show Fluorogold (whitish-blue) and IGF-II immunoreactivity (dark-blue/black). Fluorogold label in cells deeper in the tissue is attenuated by the section thickness and appears dimmer. Section thicknesses: $A-D$, 10 $\mu \mathrm{m} ; F, 20 \mu \mathrm{m} ; E, G, 40 \mu \mathrm{m}$. Scale bars, $10 \mu \mathrm{m}$.
} 
the cerebrospinal fluid, which has high titers of IGF-II produced by the choroid plexus and leptomeninges. Clearly, more work is necessary to address the functional relationship between sites of IGF-II production and peptide accumulation and before we can decide whether the IGF-II peptide exerts its effect in all cases by acting on the same cellular processes.

\section{Perspectives}

Our study suggests a correlation between IGF-II expression and neuronal plasticity. More definitive insights should come from interfering with IGF-II expression in the songbird brain through the use of selective lesioning methods (Scharff et al., 1994) as well as from blocking IGF-II at the transcriptional (Castro-Alamancos and Torres-Aleman, 1994) and translational (Nielsen et al., 1995) levels. It is likely that the striking pattern of IGF-II mRNA and peptide distribution that we have described in songbirds is just the first glimpse of a complex system that includes not only the IGFs but also their receptors and the binding proteins that modulate the bioavailability of the IGFs (for review, see Jones and Clemmons, 1995). HVC may be a particularly compelling place to study these events because this nucleus, which shows striking levels of IGF-II expression and adult neuronal replacement, also governs the acquisition and production of a changeable and quantifiable learned behavior.

\section{REFERENCES}

Altman J (1969) Autoradiographic and histological studies of postnatal neurogenesis. IV. Cell proliferation and migration in the anterior forebrain, with special reference to persisting neurogenesis in the olfactory bulb. J Comp Neurol 137:433-458.

Altman J, Bayer SA (1993) Are new neurons formed in the brains of adult mammals? In: Neuronal cell death and repair (Cuello AC, ed), pp 203-225. The Netherlands: Elsevier.

Alvarez-Buylla A (1992) Neurogenesis and plasticity in the CNS of adult birds. Exp Neurol 115:110-114.

Alvarez-Buylla A, Buskirk DR, Nottebohm F (1987) Monoclonal antibody reveals radial glia in adult avian brain. J Comp Neurol 264:159-170.

Alvarez-Buylla A, Theelen M, Nottebohm F (1988a) Birth of projection neurons in the high vocal center of the canary forebrain before, during and after song learning. Proc Natl Acad Sci USA 85:8722-8726.

Alvarez-Buylla A, Theelen M, Nottebohm F (1988b) Mapping of radial glia and of a new cell type in adult canary brain. J Neurosci 8:2702-2712.

Alvarez-Buylla A, Kirn JR, Nottebohm F (1990) Birth of projection neurons in adult avian brain may be related to perceptual or motor learning. Science 249:1444-1446.

Ayer-Le Lièvre C, Stahlbom P-A, Sara V (1991) Expression of IGF-I and -II mRNA in the brain and facial region of the rat fetus. Development 111:105-115.

Barnea A, Nottebohm F (1994) Seasonal recruitment of hippocampal neurons in adult free-ranging black-capped chickadees. Proc Natl Acad Sci USA 91:11217-11221.

Beck F, Samani NJ, Byrne S, Morgan K, Gebhard R, Brammar WJ (1988) Histochemical localization of IGF-I and -II mRNA in the rat between birth and adulthood. Development 104:29-39.

Bondy CA (1991) Transient IGF-I gene expression during the maturation of functionally related central projection neurons. J Neurosci 11:3442-3455.

Bondy C, Lee W-H (1993) Correlation between insulin-like growth factor (IGF)-binding protein 5 and IGF-I gene expression during brain development. J Neurosci 13:5092-5104.

Bondy CA, Werner H, Roberts Jr CT, LeRoith D (1992) Cellular pattern of type-I insulin-like growth factor receptor gene expression during maturation of the rat brain: comparison with insulin-like growth factors I and II. Neuroscience 46:909-923.

Bottjer SW, Halsema KA, Brown SA, Miesner EA (1989) Axonal connections of a forebrain nucleus involved with vocal learning in zebra finches. J Comp Neurol 279:312-326.

Burek MJ, Nordeen KW, Nordeen EJ (1990) Neuron loss and addition in developing zebra finch song nuclei are independent of auditory experience during song learning. J Neurobiol 22:215-223.

Castro-Alamancos MA, Torres-Aleman I (1994) Learning of the conditioned eye-blink response is impaired by an antisense insulin-like growth factor I oligonucleotide. Proc Natl Acad Sci USA 91:10203-10207.

Chew SJ, Mello C, Nottebohm F, Jarvis E, Vicario DS (1995) Decrements in auditory responses to a repeated conspecific song are longlasting and require two periods of protein synthesis in the songbird forebrain. Proc Natl Acad Sci USA 92:3406-3410.

Chew SJ, Vicario DS, Nottebohm F (1996) A large-capacity memory system that recognizes the calls and songs of individual birds. Proc Natl Acad Sci USA 93:1950-1955.

Chomczynski P, Sacchi N (1987) Single-step method of RNA isolation by acid guanidinium thiocyanate-phenol-chloroform extraction. Anal Biochem 162:156-159.

Clayton DF, Huecas ME, Sinclair-Thompson EY, Nastiuk KL, Nottebohm F (1988) Probes for rare mRNAs reveal distributed cell subsets in canary brain. Neuron 1:249-261.

Corotto FS, Henegar JR, Maruniak JA (1994) Odor deprivation leads to reduced neurogenesis and reduced neuronal survival in the olfactory bulb of the adult mouse. Neuroscience 61:739-744.

Couce ME, Weatherington AJ, McGinty J (1992) Expression of insulinlike growth factor-II (IGF-II) and IGF-II mannose-6-phosphate receptor in the rat hippocampus: an in situ hybridization and immunocytochemical study. Endocrinology 131:1636-1642.

Darling DC, Brickell PM (1996) Nucleotide sequence and genomic structure of the chicken insulin-like growth factor-II (IGF-II) coding region. Gen Comp Endocrinol 102:283-287.

D'Mello SR, Galli C, Ciotti T, Calissano P (1993) Induction of apoptosis in cerebellar granule neurons by low potassium: inhibition of death by insulin-like growth factor I and cAMP. Proc Natl Acad Sci USA 90:10989-10993.

Eales L (1985) Song learning in zebra finches: some effects of song model availability on what is learnt and when. Anim Behav 33:1293-1300.

Edbladh M, Fex-Svenningsen A, Ekstrom PA, Edstrom A (1994) Insulin and IGF-II, but not IGF-I, stimulate the in vitro regeneration of adult frog sciatic sensory axons. Brain Res 641:76-82.

Efstratiadis A (1994) IGFs and dwarf mice: genetic and epigenetic control of embryonic growth. In: Frontiers in endocrinology: developmental endocrinology, Vol 6 (Sizonenko PC, Aubert ML, Vassalli J-D, eds), pp 27-42. Rome: Ares-Serono Symposia.

Galli C, Meucci O, Scorziello A, Werge TM, Calissano P, Schettini G (1995) Apoptosis in cerebellar granule cells is blocked by high $\mathrm{KCl}$, forskolin, and IGF-I through distinct mechanisms of action: the involvement of intracellular calcium and RNA synthesis. J Neurosci 15:1172-1179.

Goldman SA, Nottebohm F (1983) Neuronal production, migration, and differentiation in a vocal control nucleus of the adult female canary brain. Proc Natl Acad Sci USA 80:2390-2394.

Graham DE, Rechler MM, Brown AL, Frunzio R, Romanus JA, Bruni CB, Whitfield HJ, Nissley S, Seelig S, Berry S (1986) Coordinate developmental regulation of high and low molecular weight mRNAs for rat insulin-like growth factor II. Proc Natl Acad Sci USA 83:4519-4523.

Hanahan D, Meselson M (1983) Plasmid screening at high colony density. In: Methods in enzymology, Vol 100, Recombinant DNA, Pt B (Wu R, Grossman L, Moldave K, eds), pp 333-342. New York: Academic.

Holzenberger M, Lapointe F, Leibovici M, Ayer-Le Lièvre C (1996) The avian IGF type 1 receptor: cDNA analysis and in situ hybridization reveal conserved sequence elements and expression patterns relevant for the development of the nervous system. Dev Brain Res 97:76-87.

Immelmann K (1969) Song development in the zebra finch and other estrildid finches. In: Bird vocalizations (Hinde RA, ed), pp 61-77. New York: Cambridge UP.

Jarvis ED, Nottebohm F (1997) Motor-driven gene expression. Proc Natl Acad Sci USA 94:4097-4102.

Jarvis ED, Mello CV, Nottebohm F (1995) Associative learning and stimulus novelty influence the song-induced expression of an immediate early gene in the canary forebrain. Learning Memory 2:62-80.

Johnson F, Bottjer SW (1995) Differential estrogen accumulation among populations of projection neurons in the higher vocal center of male canaries. J Neurobiol 26:87-108.

Johnson F, Hohmann SE, DiStefano PS, Bottjer SW (1997) Neurotrophins suppress apoptosis induced by deafferentation of an avian motorcortical region. J Neurosci 17:2101-2111. 
Johnston BM, Mallard EC, Williams CE, Gluckman PD (1996) Insulinlike growth factor-1 is a potent neuronal rescue agent after hypoxicischemic injury in fetal lambs. J Clin Invest 97:300-308.

Jones JI, Clemmons DR (1995) Insulin-like growth factors and their binding proteins: biological actions. Endocr Rev 16:3-34.

Kaplan MS, McNelly NA, Hinds JW (1985) Population dynamics of adult-formed granule neurons of the rat olfactory bulb. J Comp Neurol 239:117-125.

Kimpo RR, Doupe AJ (1997) FOS is induced by singing in distinct neuronal populations in a motor network. Neuron 18:315-325.

Kirn JR, Nottebohm F (1990) Neuronal clusters: incorporation sites for neurons born in adult canary forebrain. Soc Neurosci Abstr 16:1249.

Kirn JR, Alvarez-Buylla A, Nottebohm F (1991) Production and survival of projection neurons in a forebrain vocal center of adult male canaries. J Neurosci 11:1756-1762.

Kirn J, O'Loughlin B, Kasparian S, Nottebohm F (1994) Cell death and neuronal recruitment in the high vocal center of adult male canaries are temporally related to changes in song. Proc Natl Acad Sci USA 91:7844-7848.

Konishi M, Akutagawa E (1985) Neuronal growth, atrophy, and death in a sexually dimorphic song nucleus in the zebra finch brain. Nature 315:145-147.

Konishi Y, Takahashi K, Chui D-H, Rosenfeld RG, Himeno M, Tabira T (1994) Insulin-like growth factor II promotes in vitro cholinergic development of mouse septal neurons: comparison with the effects of insulin-like growth factor I. Brain Res 649:53-61.

Kotani K, Tsuji M, Oki A, Kashihara T, Yamada K (1993) IGF-II producing hepatic fibrosarcoma associated with hypoglycemia. Intern Med 32:897-901.

Krebs JK, Sherry DF, Healy SD, Perry VH, Vaccarino AL (1989) Hippocampal specialization of food-storing birds. Proc Natl Acad Sci USA 86:1388-1392.

Lee W-H, Michiels KM, Bondy CA (1993) Localization of insulin-like growth factor binding protein-2 mRNA during postnatal brain development: correlation with insulin-like growth factors I and II. Neuroscience 53:251-265.

LeRoith D, Werner H, Beitner-Johnson D, Roberts Jr CT (1995) Molecular and cellular aspects of the insulin-like growth factor I receptor. Endocr Rev 16:143-163.

Liu JP, Lauder JM (1992) S-100 beta and insulin-like growth factor-II differentially regulate growth of developing serotonin and dopamine neurons in vitro. J Neurosci Res 33:248-256.

Lo DC (1995) Neurotrophic factors and synaptic plasticity. Neuron 15:979-981.

Lois C, Alvarez-Buylla A (1994) Long-distance neuronal migration in the adult mammalian brain. Science 264:1145-1148.

Ludwig T, Eggenschwiler J, Fisher P, Dercole AJ, Davenport ML, Efstratiadis A (1996) Mouse mutants lacking the type 2 IGF receptor are rescued from perinatal lethality in IGF-II and IGF1R null backgrounds. Dev Biol 177:517-535.

Lund PK, Moats-Staats BM, Hynes MA, Simmons JG, Jansen M, D'Ercole AJ, Van Wyk JJ (1986) Somatomedin-C/insulin-like growth factor-I and insulin-like growth factor-II mRNAs in rat fetal and adult tissues. J Biol Chem 261:14539-14544.

Marks JL, Porte Jr D, Baskin DG (1991) Localization of type I insulinlike growth factor receptor messenger RNA in the adult rat brain by in situ hybridization. Mol Endocrinol 5:1158-1168.

Mello CV, Clayton D (1995) Differential induction of the ZENK gene in the avian forebrain and song control circuit after metrazole-induced depolarization. J Neurobiol 26:145-161.

Mooney R, Rao M (1994) Waiting periods versus early innervation: the development of axonal connections in the zebra finch song system. J Neurosci 14:6532-6543.

Mossner J, Roach E, Goldfine ID, Williams JA (1986) Autoradiographic analysis of ${ }^{125}$ I-insulin-like growth factor II internalization into pancreatic acini. Diabetes Res Clin Pract 2:75-82.

Nielsen FC (1992) The molecular and cellular biology of insulin-like growth factor II. Prog Growth Factor Res 4:257-290.

Nielsen FC, Ostergaard L, Nielsen J, Christiansen J (1995) Growthdependent translation of IGF-II mRNA by a rapamycin-sensitive pathway. Nature 377:358-362.

Nieto-Bona MP, Garcia-Segura LM, Torres-Aleman I (1993) Orthograde transport and release of insulin-like growth factor I from the inferior olive to the cerebellum. J Neurosci Res 36:520-527.
Nixdorf-Bergweiler BE, Lips MB, Heinemann U (1995) Electrophysiological and morphological evidence for a new projection of LMANneurones towards area X. NeuroReport 6:1729-1732.

Nordeen KW, Nordeen EJ (1988a) Projection neurons within a vocal motor pathway are born during song learning in zebra finches. Nature 334:149-151.

Nordeen KW, Nordeen EJ (1988b) Sex and regional differences in the incorporation of neurons born during song learning in zebra finches. J Neurosci 8:2869-2874.

Nottebohm F, Stokes TM, Leonard CM (1976) Central control of song in the canary, Serinus canaria. J Comp Neurol 165:457-486.

Nottebohm F, Kelley DB, Paton JA (1982) Connections of vocal control nuclei in the canary telencephalon. J Comp Neurol 207:344-357.

Nottebohm F, Nottebohm M, Crane LA, Wingfield JC (1987) Seasonal changes in gonadal hormone levels and their relationship to song. Behav Neural Biol 47:197-211.

Nottebohm F, O'Loughlin B, Gould K, Yohay K, Alvarez-Buylla A (1994) The life span of new neurons in a song control nucleus of the adult canary brain depends on time of year when these cells are born. Proc Natl Acad Sci USA 91:7849-7853.

Okuhata S, Saito N (1987) Synaptic connection of thalamo-cerebral vocal nuclei of the canary. Brain Res Bull 18:35-44.

Polychronakos C, Giannoukakis N, Deal CL (1995) Imprinting of IGF2, insulin-dependent diabetes, immune function, and apoptosis: a hypothesis. Dev Genet 17:253-262.

Price PH (1979) Developmental determinants of structure in zebra finch song. J Comp Physiol Psychol 93:269-277.

Quin-Wei Y, Johnson J, Prevette D, Oppenheim RW (1994) Cell death of spinal motoneurons in the chick embryo following deafferentation: rescue effects of tissue extracts, soluble proteins, and neurotrophic agents. J Neurosci 14:7629-7640.

Sambrook J, Fritsch EF, Maniatis T (1989) Molecular cloning: a laboratory manual, 2nd Ed. Cold Spring Harbor, NY: Cold Spring Harbor Laboratory.

Scharff C, Nottebohm F (1991) A comparative study of the behavioral deficits following lesions of various parts of the zebra finch song system: implications for vocal learning. J Neurosci 11:2896-2913.

Scharff C, Kirn J, Macklis JD, Nottebohm F (1994) Effects of area X lesions on HVC and selective photolysis of the HVC-to-area X-projecting neurons. Soc Neurosci Abstr 20:165.

Simpson HB, Vicario DS (1990) Brain pathways for learned and unlearned vocalization differ in zebra finches. J Neurosci 10:1541-1556.

Sohrabji F, Nordeen EJ, Nordeen KW (1990) Selective impairment of song learning following lesions of a forebrain nucleus in the juvenile zebra finch. Behav Neural Biol 53:51-63.

Stewart CE, Rotwein P (1996) Insulin-like growth factor-II is an autocrine survival factor for differentiating myoblasts. J Biol Chem 271:11330-11338.

Sullivan KA, Feldman EL (1994) Immunohistochemical localization of insulin-like growth factor-II (IGF-II) and IGF-binding protein-2 during development in the rat brain. Endocrinology 135:540-547.

Taylor ER, Seleiro EAP, Brickell PM (1991) Identification of antisense transcripts of the chicken insulin-like growth factor-II gene. J Mol Endocrinol 7:145-154.

Thoenen H (1995) Neurotrophins and neuronal plasticity. Science 270:593-598.

Ueda K, Ganem D (1996) Apoptosis is induced by N-myc expression in hepatocytes, a frequent event in hepadnavirus oncogenesis, and is blocked by insulin-like growth factor II. J Virol 7:1375-1383.

Vates GE, Nottebohm F (1995) Feedback circuitry within a songlearning pathway. Proc Natl Acad Sci USA 92:5139-5143.

Vates GE, Vicario DS, Nottebohm F (1997) Reafferent thalamo"cortical" loops in the song system of oscine songbirds. J Comp Neurol 380:275-290.

Wild M (1993) Descending projections of the songbird nucleus robustus archistriatalis. J Comp Neurol 338:225-241.

Zackenfels K, Oppenheim RW, Rohrer H (1995) Evidence for an important role of IGF-I and IGF-II for the early development of chick sympathetic neurons. Neuron 14:731-741.

Zhou M, Ma Z, Sly WS (1995) Cloning and expression of the cDNA of chicken cation-independent mannose-6-phosphate receptor. Proc Natl Acad Sci USA 92:9762-9766. 